\title{
Consolidation and Efficiency in the Financial Sector: A Review of the International Evidence
}

\author{
Dean Amel, \\ Federal Reserve Board, Washington, DC \\ Colleen Barnes, \\ Department of Finance - Ottawa, Canada \\ Fabio Panetta \\ Research Department, Bank of Italy \\ Carmelo Salleo \\ Research Department, Bank of Italy
}

This draft: August 15, 2002

\begin{abstract}
In response to fundamental changes in regulation and technology, the financial industry around the world is undergoing an unprecedented wave of consolidation. A growing body of empirical literature has attempted to measure the efficiency gains from M\&As; however there is little sense of how the results might depend on the country, industry and time period analysed. In this paper we review critically works that cover the main sectors of the financial industry (commercial and investment banks, insurance and asset management companies) in the major industrialised countries over the last twenty years, searching for common patterns that transcend national and sectoral peculiarities. We find that consolidation in the financial sector is beneficial up to a relatively small size in order to reap economies of scale, but there is little evidence that mergers yield economies of scope or gains in managerial efficiency.
\end{abstract}

Address for correspondence: Dean Amel, Federal Reserve Board, Washington, DC 20051 (USA), Ph: 202-452-2911, fax: 202-728-5838, e-mail: damel@frb.gov. Colleen Barnes, Department of Finance Canada, Ottawa, Ontario K1A 0G5. Fabio Panetta, Banca d'Italia, Via Nazionale 91, 00184, Rome (Italy). Ph.: +39-06-47924143, fax +39-06-47923723, e-mail: panetta.fabio@insedia.interbusiness.it. Carmelo Salleo, Banca d'Italia, Via Nazionale 91, 00184, Rome (Italy). Ph.: +39-06-47924386, fax +39-06-47923723, e-mail: salleo.carmelo@insedia.interbusiness.it.

Key words: Mergers, Efficiency, Bank Mergers

JEL Classification Code : G21, G34, L1.

* Dean Amel is with the Board of Governors of the Federal Reserve Board System, Washington, D.C., U.S.A. Colleen Barnes is with the Ministry of Finance, Ottawa, Canada. Fabio Panetta and Carmelo Salleo are with the Research Department of the Banca d'Italia, Rome, Italy. The opinions expressed in this paper are the authors' own and do not necessarily reflect those of the Board of Governors, the Ministry of Finance of Canada or the Bank of Italy. This paper draws heavily on the work we have done for Chapter V of the G-10 Report on Financial Sector Consolidation. We thank for their comments and suggestions Dominik Egli, Myron Kwast, Stephen Rhoades and Gerry Salembier. 


\section{Introduction}

The last fifteen years have witnessed an unprecedented number of mergers and acquisitions (M\&As) in most countries, in mature and innovative sectors alike, from retailing to telecommunications. According to Thomson Financial, there were 34,147 M\&As between 1996 and 2001, compared with 19,996 between 1990 and 1995 (see Table 1). The total value of transactions rose from $\$ 1,390$ billion to $\$ 8,135$ billion.

M\&A activity was especially pronounced in the financial sector. Over 10,000 financial firms were acquired in the major industrial countries from 1990 to 2001, including 246 deals in which the acquired firm had a market value greater than $\$ 1$ billion. The level of activity increased toward the end of the decade for all types of acquisitions: there were 93 deals worth more than $\$ 1$ billion in the six years from 1990 to 1996 and 153 between 1997 and 2001. Both within-industry and cross-industry deals increased in intensity. The rate of consolidation has soared both domestically and internationally, but the great majority of M\&A activity still involves firms from the same country. ${ }^{1}$

The main motivations for this unprecedented wave of consolidation in the financial sector are common to most countries. In response to fundamental changes in regulation and technology, financial institutions have attempted to improve their efficiency and attract new customers by increasing their geographical reach and the range of products they offer. The desire to preserve falling margins by increasing market share and to attract new customers is often

\footnotetext{
${ }^{1}$ See Group of Ten (2001), pp. 31-42.
} 
Mergers and Acquisitions in the main industrial countries ${ }^{(1)}$

\begin{tabular}{|c|c|c|c|c|c|c|c|c|c|c|c|c|c|c|c|c|c|c|}
\hline & \multicolumn{6}{|c|}{ All Meraers and Acauisitions } & \multicolumn{12}{|c|}{ Meraers and Acauisitions in the Financial Sector ${ }^{(2)}$} \\
\hline & \multicolumn{3}{|c|}{ 1990-1995 } & \multicolumn{3}{|c|}{$1996-2001$} & \multirow{2}{*}{\multicolumn{2}{|c|}{ TOTAL 1990-95 }} & \multirow{2}{*}{\multicolumn{2}{|c|}{$\begin{array}{l}\text { of which: } \\
\qquad \text { Banks }^{(3)}\end{array}$}} & \multirow{2}{*}{\multicolumn{2}{|c|}{$\begin{array}{l}\text { of which: } \\
\text { Insurance } \\
\text { Comnanies } \\
\end{array}$}} & \multirow{2}{*}{\multicolumn{2}{|c|}{ TOTAL 1996-2001 }} & \multirow{2}{*}{\multicolumn{2}{|c|}{$\begin{array}{l}\text { of which: } \\
\text { Banks }^{(3)}\end{array}$}} & \multirow{2}{*}{\multicolumn{2}{|c|}{$\begin{array}{l}\text { of which: } \\
\text { Insurance } \\
\text { Comnanies } \\
\end{array}$}} \\
\hline & & & & & & & & & & & & & & & & & & \\
\hline & \multicolumn{3}{|c|}{ Number $\underline{\text { Total Value }}$} & \multirow[t]{2}{*}{ Number $=$} & \multicolumn{2}{|l|}{$\begin{array}{l}\text { Total Value } \\
\end{array}$} & \multirow{2}{*}{ Number } & \multirow{2}{*}{\begin{tabular}{c|c} 
Total Value & 1 \\
$\$$ billions &
\end{tabular}} & \multirow{2}{*}{ Number } & \multirow{2}{*}{\begin{tabular}{c|} 
Total Value \\
$\$$ billions
\end{tabular}} & \multirow{2}{*}{ Number } & \multirow{2}{*}{\begin{tabular}{c|} 
Total Value \\
$\$$ billions
\end{tabular}} & \multirow[t]{2}{*}{ Number } & \multirow{2}{*}{$\begin{array}{c}\text { Total Value } \\
\$ \text { billions }\end{array}$} & \multirow{2}{*}{\multicolumn{2}{|c|}{\begin{tabular}{|c|} 
Number Total Value \\
$\$$ billions
\end{tabular}}} & \multirow{2}{*}{\multicolumn{2}{|c|}{$\begin{array}{c}\begin{array}{c}\text { Number } \\
\text { Total Value } \\
\$ \text { billions }\end{array}\end{array}$}} \\
\hline & & $\$$ billions & $\%$ of GDP & & \$ billions & $\%$ of GDP & & & & & & & & & & & & \\
\hline Australia & 628 & 29,5 & 1,5 & 1.423 & 91,7 & 4,0 & 136 & 4,5 & 53 & 2,4 & 23 & 1,1 & 268,0 & 25,2 & 91 & 13,2 & 22 & 3,3 \\
\hline Belgium & 251 & 7,1 & 0,5 & 354 & 57,8 & 3,9 & 67 & 4,5 & 21 & 0,8 & 18 & 2,7 & 70,0 & 32,9 & 34 & 28,1 & 12 & 1,0 \\
\hline Canada & 1.421 & 41,6 & 1,2 & 2.888 & 287,4 & 7,3 & 156 & 3,9 & 52 & 1,6 & 19 & 0,9 & 321,0 & 36,0 & 112 & 15,0 & 42 & 8,8 \\
\hline France & 1.663 & 81,9 & 1,0 & 1.563 & 269,6 & 3,2 & 314 & 25,5 & 148 & 11,8 & 21 & 2,9 & 227,0 & 73,7 & 96 & 44,6 & 42 & 21,0 \\
\hline Germany & 1.913 & 37,3 & 0,3 & 3.039 & 437,0 & 3,5 & 234 & 11,0 & 123 & 2,4 & 39 & 6,2 & 379,0 & 82,6 & 229 & 68,6 & 46 & 12,7 \\
\hline Italy & 852 & 55,0 & 0,8 & 1.048 & 198,2 & 2,9 & 251 & 24,8 & 147 & 19,2 & 33 & 4,9 & 236,0 & 97,6 & 138 & 80,4 & 44 & 13,4 \\
\hline Japan & 216 & 56,1 & 0,2 & 2.291 & 234,5 & 0,9 & 46 & 45,4 & 29 & 44,4 & 2 & 0,2 & 491,0 & 138,1 & 236 & 119,1 & 48 & 15,3 \\
\hline Netherland & 565 & 25,6 & 1,3 & 635 & 127,2 & 5,5 & 123 & 14,5 & 36 & 10,9 & 38 & 3,3 & 88,0 & 33,9 & 24 & 5,9 & 22 & 21,9 \\
\hline Spain & 510 & 25,6 & 0,8 & 1.042 & 99,3 & 2,8 & 120 & 8,3 & 66 & 5,9 & 35 & 2,3 & 153,0 & 34,2 & 67 & 31,2 & 42 & 1,1 \\
\hline Sweden & 473 & 33,8 & 2,4 & 793 & 126,0 & 8,9 & 84 & 4,1 & 44 & 2,8 & 7 & & 81,0 & 21,2 & 38 & 16,9 & 6 & 2,8 \\
\hline Switzerland & 412 & 14,6 & 1,0 & 485 & 85,9 & 5,6 & 111 & 4,9 & 81 & 3,3 & 9 & 1,2 & 87,0 & 35,2 & 43 & 24,2 & 14 & 9,7 \\
\hline United Kingdom & 2.349 & 170,9 & 2,7 & 4.484 & 848,6 & 10,3 & 386 & 41,4 & 140 & 33,0 & 77 & 2,0 & 750,0 & 226,1 & 279 & 114,4 & 141 & 76,0 \\
\hline United States & 8.743 & 811,2 & 2,1 & 14.102 & $5.272,3$ & 9,7 & 2.341 & 205,3 & 1.691 & 156,6 & 275 & 25,6 & $2.902,0$ & $1.138,2$ & 1.796 & 754,9 & 364 & 192,5 \\
\hline \multicolumn{19}{|l|}{ Total Main Industrial } \\
\hline Countries ${ }^{(4)}$ & 19.996 & 1.390 .2 & 1.3 & 34.147 & 8.135 .5 & 6.1 & 4.369 & 398.2 & 2.631 & 295.1 & 596 & 53.3 & 6.053 .0 & 1.974 .9 & 3.183 & 1.316 .6 & 845 & 379.4 \\
\hline of which: Euro Area & 6.767 & 256,0 & 0,7 & 9.696 & $1.310,3$ & 3,4 & 1.317 & 99,8 & 655 & 59,6 & 227 & 24,1 & $1.406,0$ & 412,3 & 700 & 302,8 & 249 & 79,2 \\
\hline World & 26.062 & 1.570 .3 & & 50.787 & $8.960,2$ & & 5.725 & 460.9 & 3.363 & 340,3 & 773 & 62.1 & 9.777 .0 & 2.232 .9 & 4.781 & 1.494 .9 & 1.328 & 418.7 \\
\hline
\end{tabular}

Sources: Thomson Financial and SDC Platinum.

(1) Mergers and acquisitions involving majority interests. (2) The sectors refer to that of the company being acquired (3) Includes: Commercial Banks, Bank Holding Companies, Saving and Loans,

Mutual Savings Banks, Credit Institutions, Real Estate; Mortgage Bankers and Brokers. (4) G10 countries, Australia and Spain. 
There are several ways in which M\&As can improve efficiency. First, the larger firms that result from consolidation may gain access to cost-saving technologies or spread their fixed costs over a larger base, thus reducing average costs. Efficiency gains may also derive from the exploitation of economies of scope: the deal may allow the merging parties to enter new markets and cross-sell their products to a wider customer base. Finally, consolidation may improve managerial efficiency.

M\&As on the scale witnessed by the financial sector in the last decade have profound effects on the firms involved, their competitors and their customers. Yet, the effect of consolidation on the performance of the institutions involved is not well understood. In particular, the extent of exploitable scale and scope economies might be smaller than commonly thought, and efficiency gains resulting from better management might be elusive in large, complex institutions.

These considerations apply to most industries that have undergone a wave of consolidation in the nineties, ${ }^{2}$ but they are particularly relevant from a policy perspective for the financial industry. Social costs arising from M\&As can take three forms. First, for some financial products (in particular deposits and small business lending) markets are mainly local; therefore, M\&As among operators with large market shares might cause adverse price changes, harming consumers. ${ }^{3}$ Second, M\&As might contribute to diverting the focus of some participants from small business lending, which relies on soft information at the local level, to less custom-made products that are more easily manageable within large organizations. ${ }^{4}$ Third, consolidation can increase the risk of the operators involved, both at the individual level (by generating large and complex institutions that may suffer from diseconomies of scale) and at the systemic level. ${ }^{5}$ Therefore,

\footnotetext{
${ }^{2}$ See Andrade, Mitchell and Stafford (2001).

${ }^{3}$ See Prager and Hannan (1998) and Focarelli and Panetta (2002) for deposits and Sapienza (2002) for loans.

${ }^{4}$ See Berger, Saunders, Scalise and Udell (1998) and Berger, Miller,Petersen, Rajan and Stein (2002).

${ }^{5}$ Chapter III of the report by the Group of Ten (2001) discusses the effect of consolidation on risk.
} 
quantifying efficiency gains from M\&As for the financial sector becomes extremely important as a first step towards analyzing the trade-off between these gains and the potential adverse effects.

In this paper we organize what is by now an established body of research on M\&As and efficiency in the financial sector along industry and country lines, in order to shed light on common features and understand the main differences. This review differs from others ${ }^{6}$ in that, while not pretending to be exhaustive, it attempts to reach a level of generality by covering most industrialized countries (the U.S., Europe, Japan, Australia, and Canada) and financial industries (commercial banks, insurance and asset management companies and investment banks). This way, we are able to confirm that some patterns are independent of institutional features and measurement techniques, while others may be industryor country-specific.

The paper is organized as follows: in section 2 we review what is generally meant by efficiency improvement. We then gauge the impact of consolidation on the performance of financial institutions on the basis of a review of the evidence available for the main industrialized countries on the effect of M\&As on the efficiency of commercial banks (section 3), insurance companies (section 4), investment banks and asset management companies (section 5). In section 6 we describe briefly the impact of cross-border and cross-industry transactions. Section 7 concludes.

\section{How Do We Measure Efficiency?}

Efficiency is a broad concept that can be applied to many dimensions of a firm's activities. In this section we review briefly the most commonly used indicators of efficiency.

\footnotetext{
${ }^{6}$ See, e.g., Berger, Demsetz and Strahan (1999).
} 
According to narrow technical definitions, a firm is cost efficient if it minimizes costs for a given quantity of output; it is profit efficient if it maximizes profits for a given combination of inputs and outputs. These two definitions take size and technology as given and focus on how production factors are combined, by comparing a firm's actual costs or profits with the costs or profits of the best practice institution. Consolidation may increase efficiency, by transferring superior managerial skills from the bidder to the target. However, the opposite may also happen, for example when the managers of the bidder enter into new geographic or product markets or when the merger is motivated by empirebuilding strategies pursued by relatively inefficient managers.

A broader concept of efficiency considers scale and scope economies: an efficient firm is one that reaches the optimal size for its industry (scale) and that produces the optimal mix of products given the prices of their production factors (scope). Scale economies often arise from the ability of larger firms to allocate fixed costs, such as advertising expenses or the cost of technology, across a greater volume of output. Revenue scale economies can arise if customers prefer to deal with large banks, for example because of the convenience of one-stop shopping or because of the importance of the branch network. ${ }^{7}$ Scope economies may result from sharing information, such as knowledge of customers' habits, across product lines. Beyond a certain scale or scope, diseconomies may appear as managers move beyond their areas of expertise or as size and the internal hierarchical structure of firms reduces the control of owners over managers. Minimum efficient size and optimal product mix vary with technology, regulation and consumers' tastes. Therefore, there could be wide variations in firm structure across time, industries and countries if firms fully exploit scale and scope economies.

Different definitions of efficiency call for different measurement methodologies. The simplest approach consists of comparing balance sheet ratios that describe costs (e.g., operating costs over gross income) and profitability (e.g., return on 
assets or on equity). However, this methodology does not fully take into account differences in exogenous prices of inputs and outputs faced by different financial firms (for example because their market power differs or simply because they are located in different regions). More complex analyses measure managerial cost and profit efficiency by comparing firms to the best practice of the industry, as determined by statistical methods, taking into account for each institution the inputs, outputs and the prices it faces. ${ }^{8}$

One method estimates a stochastic frontier (a combination of the factors just mentioned) along which all efficient firms would operate, and the distance of each actual firm from the frontier is taken as a measure of its (in)efficiency. This method should be considered with a certain degree of caution, given that it is based on the presumption that the residuals of the estimated frontier are highly correlated with the managerial inefficiency of the banks. Since estimated residuals are, by definition, the portion of the variation in costs or profits that cannot be explained by the model, using these residuals as measures of efficiency may be problematic. Also, while the extreme values of cost or profit distributions are often truncated to an arbitrary extent before stochastic frontiers are estimated, these methods still rely on fairly extreme observations to determine the behavior of efficient firms, and such observations may be subject to measurement error to a greater extent than other firms in the sample. Furthermore, many studies regress residuals on factors that may explain differences in efficiency across firms. However, it is not clear why such factors are not controlled for in the original cost or profit function estimation, likely a more efficient way to capture their effects than through a second regression on estimated residuals.

\footnotetext{
7 The importance of a bank's branch network is documented by Kennickel, McCluer and Sunden (1997). Consumers' preference for one-stop shopping is documented in Kwast, McCluer and Wolken (1997).

${ }^{8}$ Berger and Mester (1997) and Cummins and Weiss (2000) review most estimation techniques and provide a comprehensive bibliography on the subject for banks and insurance companies respectively. Therefore, we will just sketch out the most commonly used methods of estimating firm-level efficiency and the drawbacks of each method.
} 
A second method estimates cost or profit frontiers non-parametrically. This method assumes that there is no random error in the data; it ascribes all residuals from the estimation procedure to inefficiency.

In order to evaluate economies of scale and scope, the shape of the frontier, given by the existing technologies, is investigated: if the performance of firms on the frontier (i.e., firms that combine optimally the existing resources) would improve by changing their size or product mix, then there is still room for exploiting economies of scale or scope.

Given that both cost and profit functions are duals of the production function, ${ }^{9}$ the choice of which function to study depends on the availability of data, on considerations on whether input or output prices can be considered truly exogenous, on what kind of relationships are considered more relevant for the economic analysis at hand. For example, when trade unions are negotiating the terms of a new contract a relationship of interest could be the sensitivity of total operating costs to labor costs, while in a recession it might be more interesting to know the sensitivity of banks' profits to a decrease in loans.

The impact of M\&As on firm-level efficiency can be gauged in different ways. For example, several studies investigate the relationship between size and efficiency. The results provide indirect evidence on the effects of mergers: if larger firms are more efficient, then presumably mergers will improve performance. This methodology suffers, however, from a weakness: it assumes that merged institutions are largely comparable to other larger firms; but the fact that firms are involved in a merger while others are not is an indication that they may be different in several (possibly unobservable) ways. Analyses that focus on the performance of merged institutions compared with the performance of non-

\footnotetext{
${ }^{9}$ To analyze efficiency the object of interest is the production function, i.e. how inputs combine to produce outputs. However, the data required for its direct estimation are generally not available; moreover, there are methodological issues pertaining to how to deal with differences in product quality. Therefore, researchers have generally estimated cost and profit functions, that, under rather general conditions on the properties of the production function, contain all the relevant information, i.e they are duals of the production function (see e.g. Diewert (1974)).
} 
merged ones provide direct evidence on the relationship between M\&As and efficiency. Both types of research suffer from drawbacks other than those already mentioned. Neither controls much for differences in the quality of output or the riskiness of firms. ${ }^{10}$ Product or service quality differences would likely be attributed to differences in efficiency.

Acknowledging these shortcomings, no one has devised a fully satisfactory measure of inefficiency and these studies are the only available evidence on the subject. The direct and indirect approaches are complementary; both provide information on the consequences of the consolidation process on efficiency. Research usually has been conducted by analyzing indirect evidence, mainly because databases on the direct effects of M\&As are generally not available.

Finally, for firms listed on a stock exchange, efficiency gains can be measured on the basis of stock market performance: a firm is thought to be doing well when its shares outperform a given benchmark (e.g., the industry average or an index of firms of comparable size). The overall efficiency gains from a merger are evaluated in terms of the sim of the market values of the bidder and the target: if the sum increases, the deal is supposed to create value, and vice versa if it decreases. By assumption, differences in firm risk are observed perfectly by the capital markets and incorporated in share prices; if this is not the case, these models would interpret the higher returns that typically result from increases in firm risk as increases in efficiency.

Differences in regulations, institutions and market structure across countries mean that conclusions drawn from the analysis of one country should be generalized to others only very carefully. ${ }^{11}$ On the positive side, this means that common patterns that emerge from an international comparison are particularly informative for a policy debate.

\footnotetext{
${ }^{10}$ An exception is Mester (1996).

11 Dietsch and Lozano-Vivas (2000) show that the influence of such environmental factors on measures of firm efficiency can be significant.
} 


\section{Commercial Banks}

Before analyzing the empirical evidence, we note three facts about the commercial banking industry. First, the industry really consists of two product markets: retail and wholesale banking. Retail banking is oriented towards households and small firms, while wholesale banking caters to larger firms and other financial institutions. Of course, many banks provide both services, but this only adds to the complexity of any empirical analysis. In general, research has not distinguished explicitly between retail and wholesale banking, although the focus is implicitly on retail banking, where policy issues regarding competition, regulation and consumer protection are more relevant. The remainder of this section is mainly concerned with retail banks.

Second, in countries with a heavily bank-oriented financial system, the banking industry may evolve differently than in countries where there is more scope for securities markets activities, in terms both of products offered and risk management. This should be kept in mind when making international comparisons of cost or revenue structures or economies of scale and scope. In countries with well-developed financial markets, banks provide more services than just loans and deposits and are better able to offload risks, thus maintaining more liquid balance sheets; they may behave differently from banks that rely more on traditional intermediation activities.

Finally, because of differences in regulation, in some countries commercial and investment banks are (or have been in the past) strictly separated (e.g., the U.S. until recently), while in others (such as Germany or Italy) they can operate jointly as universal banks and even have cross-shareholdings with industrial companies. These differences make for different market structures and internal organizations, again hampering international comparisons. All these warnings notwithstanding, the banking industries in the main industrialized countries share some structural features that emerge from a careful analysis. 


\subsection{Aggregate Data}

Similarities and differences among North American, European and Japanese banks emerge from the comparison of basic balance sheet ratios. Such an analysis might seem naive at first sight, but many studies find that simple accounting ratios are highly correlated with econometric estimates of efficiency. ${ }^{12}$

The relationships between the cost structure and size of North American and European commercial banks show some common features: the ratio of operating costs to gross income is higher for smaller banks (with total assets below $\$ 5$ billion) and it decreases from over 60 percent to around 55 percent for banks with assets between $\$ 20$ billion and $\$ 50$ billion (see Table 2).

The largest banks, with assets greater than $\$ 50$ billion, present the highest costs (more than 65 percent of gross income). This pattern suggests the existence of economies of scale up to a certain size, followed by diseconomies for very large banks. However, profitability rises with total assets: for North American banks the return on equity increases from 11 to 14 percent from the smallest to the largest size class; for European banks it increases from 7 to 8 percent. ${ }^{13}$ Higher operating costs are compensated by a lower ratio of equity to total assets, probably an indirect benefit of increased diversification, and by a higher share of non-interest income (more than 50 percent of gross income for North American banks, more than 30 percent for the others). For Japanese banks the picture is more straightforward: the ratio of operating costs to gross income decreases as firms become larger; profitability is low or negative because of the deteriorating economic and financial conditions of the country since the mid 1990s.

SIZE AND PERFORMANCE OF COMMERCIAL BANKS

Table 2

\footnotetext{
Area Variables $<\$ 5$ bill. $\$ 5-\$ 20$ bill. $\$ 20-\$ 50$ bill. $>\$ 50$ bill.

${ }^{12}$ See, for example, Berger and Mester (1997) and Peristiani (1997).

${ }^{13}$ Return on equity, unlike return on assets, is influenced by the capital structure of the bank; however, given that the capital structure is endogenously determined by the bank's management, it can also be considered as part of the measurement of efficiency.
} 


\begin{tabular}{|c|c|c|c|c|c|c|c|c|c|}
\hline & & No. & Average & No. & Average & No. & Average & No. & Average \\
\hline \multirow{3}{*}{$\begin{array}{l}\text { North } \\
\text { America }\end{array}$} & $\frac{\text { Non-Int. Income }}{\text { Gross Income }}$ & 266 & 21.5 & 97 & 29.2 & 29 & 28.2 & 19 & 53.4 \\
\hline & $\frac{\text { Operating Costs }}{\text { Gross Income }}$ & 266 & 60.9 & 96 & 59.8 & 29 & 55.4 & 19 & 67.8 \\
\hline & Return on Equity & 266 & 11.2 & 97 & 13.5 & 29 & 13.5 & 19 & 14.1 \\
\hline \multirow{3}{*}{ Europe } & $\frac{\text { Non-Int. Income }}{\text { Gross Income }}$ & 539 & 19.2 & 169 & 24.6 & 50 & 20.2 & 64 & 30.8 \\
\hline & $\frac{\text { Operating Costs }}{\text { Gross Income }}$ & 543 & 63.1 & 183 & 61.6 & 55 & 55.6 & 63 & 65.5 \\
\hline & Return on Equity & 559 & 7.1 & 185 & 7.4 & 48 & 7.2 & 58 & 8.2 \\
\hline \multirow{3}{*}{ Japan } & $\frac{\text { Non-Int. Income }}{\text { Gross Income }}$ & 15 & .4 & 63 & 9.2 & 29 & 8.9 & 26 & 30.0 \\
\hline & $\frac{\text { Operating Costs }}{\text { Gross Income }}$ & 17 & 76.9 & 63 & 69.5 & 29 & 67.9 & 26 & 60.4 \\
\hline & Return on Equity & 17 & -1.3 & 63 & 0.1 & 29 & 0.5 & 26 & -3.2 \\
\hline
\end{tabular}

Source: Fitch-IBCA data for commercial banks of G-10 countries; banks are ranked by assets in billion U.S. dollars. All variables are averaged over the 1994-1997 period; the distribution is truncated at the top and bottom 10 percent.

As for managerial efficiency, the dispersion of cost and profitability ratios can be taken as a proxy for the distance between the best and the worst performers. In North America, among banks with less than $\$ 5$ billion of assets, the costs of those in the top quartile represent 55 percent of gross income and the return on equity is above 15 percent (Table 3).

For banks in the bottom quartiles of the cost and profitability distributions, costs are above 65 percent of gross income and the return on equity is less than half of that of the best performers; the results are qualitatively the same for European and Japanese banks. The heterogeneity of results among banks of roughly the same size is an indication that there is room for efficiency gains. For the largest banks, with assets above $\$ 50$ billion, there is less heterogeneity, at least in North America (except for the share of non-interest income, which varies widely, perhaps due to the simultaneous presence of traditional intermediaries and more innovative banks). This could be due to the fact that the largest banks largely operate in wholesale markets where there is more competition and less room for complacent behavior. For European and Japanese banks, the differences between the top and bottom quartiles are similar to those recorded for the smaller banks; again, heterogeneity indicates room for efficiency improvement. 
Table 3

DISPERSION OF PERFORMANCE MEASURES OF COMMERCIAL BANKS

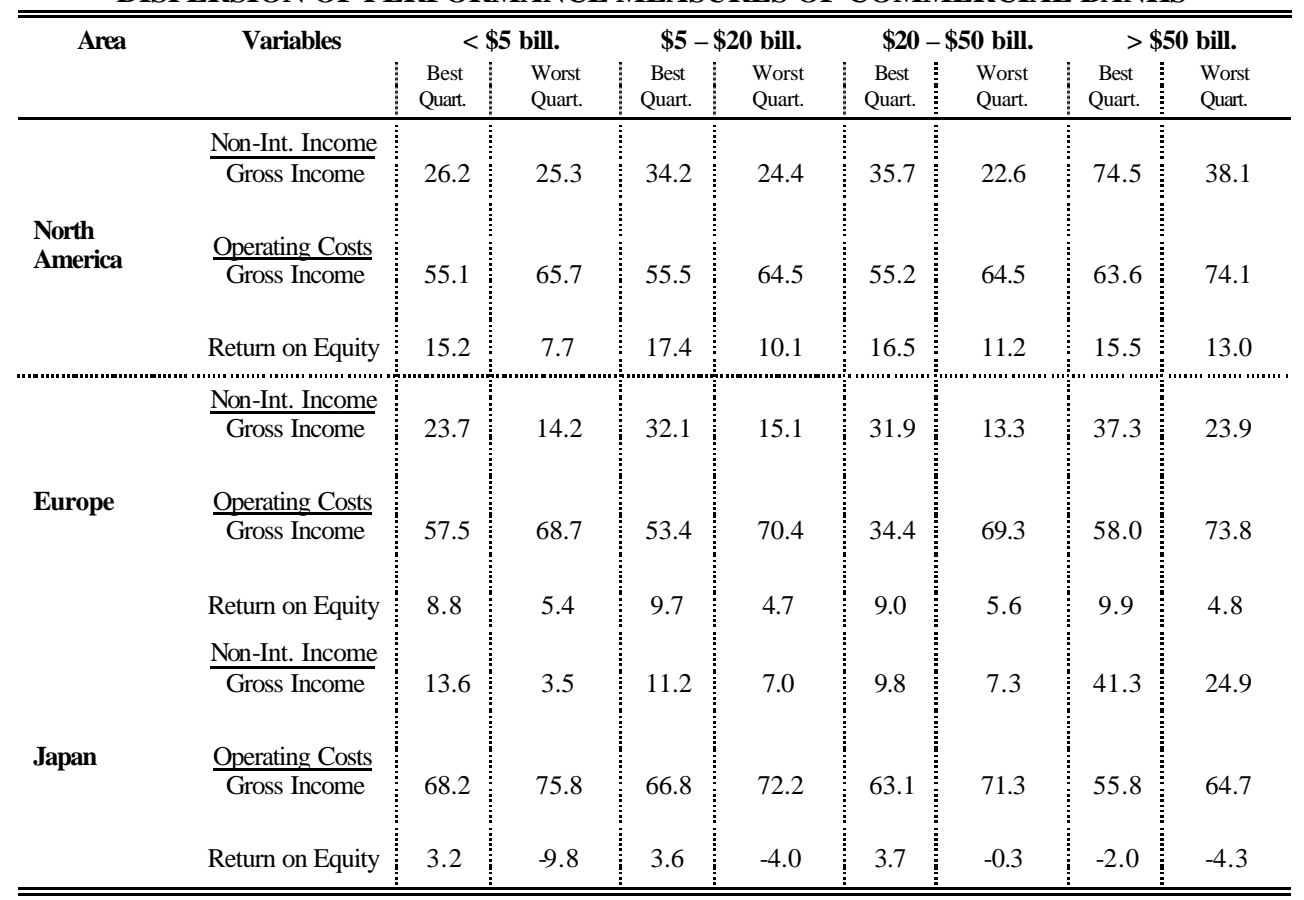

Source: Fitch-IBCA data for commercial banks of G10 countries; banks are ranked by assets in billion U.S. dollars. All variables are averaged over the 1994-1997 period; the distribution is truncated at the top and bottom 10 percent.

\subsection{Cost and Profit Efficiency}

Efficiency is almost always measured relative to a domestic benchmark; international comparisons of efficiency levels are problematic because the best banks of each country operate with different technologies that are not directly comparable.

For the U.S. and Europe most studies of cost efficiency find that retail banks operate on average at between 10 and 20 percent below the efficient cost frontier, i.e., their costs are higher by 10 to 20 percent than those of the best institutions. ${ }^{14}$

\footnotetext{
${ }^{14}$ See, for example, Berger and Humphrey (1997) for the U.S. and Altunbas, Molyneux and Thornton (1997) and Schure and Wagenvoort (1999) for Europe. Schure and Wagenvoort study 2000 European banks during the years 1993-1997 (i.e., after the implementation of the European Union's Second Banking Directive of 1988 and the adoption of the Single Market of 1992) and show that, on average, costs could be reduced by 16 percent; in the period examined, banks in some countries — such as the U.K., the Netherlands and Italy -
} 
For Japanese banks, the gap between the best and the average practice institution (the average cost inefficiency) is around 5 to 7 percent; ${ }^{15}$ this means that M\&As are likely to bring about smaller efficiency improvements than in banking systems with a higher dispersion of efficiency scores, i.e. with a greater difference between the best practice banks (potential acquirers, that could transfer their superior management skills) and the others. The reduction of this gap relative to the eighties (when it was estimated to be approximately 14 percent, i.e. the same level of output could have been produced by Japanese banks with 14 percent fewer resources) $)^{16}$ indicates that after the crisis of the nineties Japanese banks operate closer to their efficient frontier. However it is important to bear in mind that efficiency indicators are relative measures of performance, and say nothing on the efficiency of the industry as a whole compared to banks of other countries.

The average efficiency of Australian banks is low (58 percent in 1996) compared to best-practice banks; ${ }^{17}$ once more, this only means that the distance of Australian banks from their efficient frontier is higher than elsewhere, and does not imply that they are in worse shape, as it is impossible to compare directly industries that have production functions with different shapes. The efficiency ratios of Australian credit unions have been found to be 80 to 90 percent. However, taking into account the subsidies received by some credit unions, such as volunteer labor, free office space, etc., the efficiency ratios drop to around 60 percent. $^{18}$

\footnotetext{
achieved rapid cost-efficiency improvements, while in other countries — such as France and Germany banks had yet to start slimming down.

15 See Altunbas, Liu, Molyneux and Seth (2000). However their definition of output (total loans, securities and off-balance sheet items) is somewhat different from the traditional specification and makes their results hard to compare to others.

${ }^{16}$ See Fukuyama (1993).

17 Sathye (2001) investigates the technical and allocative efficiency of Australian banks using Data Envelopment Analysis.

18 See Esho (2001). Efficiency estimates of credit unions are usually performed separately from those of standard commercial banks, mainly because of differences in regulation and corporate objectives, although the same analytical framework is usually applied.
} 
As for banks' profit efficiency, estimates are more dispersed. Their average is around 50 percent: the average bank could be twice as profitable. ${ }^{19}$ However, these estimates are more sensitive to the specification used to measure them than are estimates of cost efficiency and are thus less robust. In general, their dispersion suggests that profits are more driven than costs by firm-specific factors such as management quality or unobservable characteristics of local demand. Therefore, there seems to be more potential for improving the overall performance of an inefficient target by increasing revenues than by reducing costs.

A caveat to this conclusion comes from the fact that, according to the duality theorems briefly recalled in section 2, the cost and profit functions are both duals of the production function. In fact, given the complexity of a bank's production function (a multiple input - multiple output firm with unobservable quality of some inputs and outputs and a degree of endogeneity in the determination of prices), efficiency estimates based on manipulation of regression residuals are subject to both specification and measurement error. One study finds very little correlation between cost and profit efficiency measures, ${ }^{20}$ this may reflect endogenous output prices: banks may differ in their market power either because they operate in different markets or because they specialize in some product niche; in this case they might have higher-than-average profits (thus seeming profit efficient) but can also afford some slack in cost control (thus seeming costinefficient). Alternatively, banks with (unobservable) high-quality products have higher profits but also higher production costs. In any event, further joint analysis of cost and profit efficiency would shed some light on estimation issues.

\section{$M \& A s$ and Cost Efficiency}

The studies that analyze the direct effect of M\&As on banks' efficiency have been performed on the basis both of balance sheet ratios and of multivariate cost and

\footnotetext{
${ }^{19}$ See, for example, Berger and Humphrey (1997), Berger, Hancock and Humphrey (1993), and Demsetz and Strahan (1997).

${ }^{20}$ See Berger and Mester (1997).
} 
profit functions. The evidence on the effects of the deals on cost efficiency varies by country.

For the U.S. there is little evidence of any improvement in cost efficiency following a merger. In particular, there seems to be no decrease in non-interest expenses or total costs and no improvement in operating income; cost efficiency also shows very little improvement. ${ }^{21}$

The evidence for European banks is broadly consistent with these results: domestic mergers among banks of equal size improve cost efficiency, but this result does not hold for all countries. ${ }^{22}$ Simulation evidence suggests that crossborder acquisitions may be associated with a reduction in the costs of the target, while little effect is found for domestic M\&As. ${ }^{23}$ The difficulties in improving cost efficiency may be related to the obstacles encountered, especially in continental Europe, to reducing banks' labor force. In fact, personnel reductions, one of the main sources of savings, are hardly an option in countries with rigid labor markets. $^{24}$

The evidence of studies that use more recent data is mixed. A number of studies for the U.S. finds that mergers produce no improvement in banks' cost efficiency, ${ }^{25}$ especially for the deals that involve very large banks. ${ }^{26}$ This may be

21 See Srinivasan (1992), Berger and Humphrey (1992b), Linder and Crane (1993), Pilloff (1996) and DeYoung (1997).

${ }^{22}$ See Vander Vennet (1996).

23 Altunbas, Molyneux and Thornton (1997) look at the cost implications of hypothetical cross-border mergers, and find that most possible mergers yield no cost efficiencies. They estimate a cost function over the existing sample of banks, then artificially merge banks by adding the quantities and averaging the prices of their inputs and outputs. This methodology does not allow for the payment of any premiums on the stock of the acquired firm nor for any transactions costs associated with the merger. Neither does it allow for any efficiencies or synergies that would arise from altering input or output levels, which are typically the principal stated purpose for mergers.

${ }^{24}$ See Focarelli, Panetta and Salleo (2002) for an analysis of the Italian market for bank M\&As.

25 See Peristiani (1997) which, unlike most studies, includes in its sample mergers that are essentially corporate reorganizations, e.g., mergers of two banks that are subsidiaries of the same bank holding company. See also, Berger (1998) and Rhoades (1998).

${ }^{26}$ See Akhavein, Berger and Humphrey (1997) and Berger (2000). 
due to the organizational diseconomies of operating larger enterprises disruptions from the M\&A process may offset most potential efficiency gains. However, another study finds cost reductions also for very large U.S. banks. ${ }^{27}$ For the U.K., significant productivity gains are associated with mergers stemming from reduced inefficiency; ${ }^{28}$ these results are consistent with the transfer of assets to a more productive management.

\section{M\&As and Profit Efficiency}

Akhavein, Berger and Humphrey (1997) find little change in cost efficiency but an improvement in profit efficiency of large U.S. banks after M\&As, especially if both merger participants were relatively inefficient prior to the merger. ${ }^{29}$ They find that, after merging, banks shift their portfolios to take on more loans and fewer securities. Their measure of profit efficiency does not account for changes in risk likely to result from such a portfolio switch; they assume that equity markets would recognize and account for any such change. They attribute gains in profit efficiency to the benefits of risk diversification: larger banks have more diversified loan portfolios and lower equity-asset ratios. ${ }^{30}$ These results may come from using a sample of U.S. banks from 1980-90, a period that coincided with the gradual lifting of the ban on interstate transactions, which allowed banks from different states, each with geographically concentrated portfolios, to merge and thus diversify their holdings. ${ }^{31}$ In addition, their findings that there is little effect on market power from large bank mergers may not translate from the United

\footnotetext{
27 See Houston, James and Ryngaert (2001). Interestingly, this study finds that the effect of revenue enhancement is not very important.

${ }^{28}$ See Haynes and Thompson (1999).

${ }^{29}$ Other relevant studies include Berger (2000), Berger, Hancock and Humphrey (1993), Berger, Humphrey and Pulley (1996), Berger and Mester (1997) and Clark and Siems (1997).

30 This paper has an unusual sample: it excludes M\&As in which the banks involved remained separate corporate entities after the consolidation, but includes mergers between banks that are subsidiaries of the same holding company. It is not clear what effect the inclusion in the sample of these corporate reorganizations has on the results.

${ }^{31}$ Consistent with this view, Berger and DeYoung (2000) find that some banking organizations are efficiently managed on a cross-regional basis.
} 
States to countries with different antitrust regulations. Berger (1998) finds similar results in a study that includes all U.S. bank mergers, both large and small, from the 1990 to 1995.

The evidence for Europe suggests that more efficient banks tend to acquire institutions in worse shape. ${ }^{32}$ Vander Vennet (1996) finds that domestic mergers of equals in EC countries have a positive impact on profitability, mainly driven by improvements in operational efficiency. However, he does not find performance improvements in full or partial domestic acquisitions of one bank by another. Vander Vennet's analysis does not control for the correlation of many of the balance sheet variables that he examines. Focarelli, Panetta and Salleo (2002) find that Italian deals that consist of the purchase of the majority (but not all) of the voting shares of the target appear to result in significant improvements, mainly due to a decrease in bad loans. For full mergers they observe that Italian banks aim to change their business focus towards providing financial services and thus increase their non-interest income, rather than to obtain efficiency gains. After the merger, they observe an increase in profitability in the long run that is related also to a more efficient use of capital.

\subsection{Scale and Scope Economies}

Perhaps the most commonly quoted source of potential gains from M\&As is the exploitation of scale economies. Banks that increase significantly their size by merging with others may have the opportunity to access cost-saving technologies or to spread fixed costs over a larger base, thus reducing average costs and improving profitability. ${ }^{33}$

Most research on the existence of scale economies in retail commercial banking finds a relatively flat $\mathrm{U}$-shaped average cost curve, with a minimum somewhere

\footnotetext{
${ }^{32}$ Berger and Humphrey (1992b) find similar results for the U.S.

33 Notice, however, that many of the same gains could be achieved by outsourcing typical back office functions.
} 
around $\$ 10$ billion of assets, depending on the sample, country and time period analyzed. Most of these studies suggest that efficiency gains from the exploitation of scale economies disappear once a certain size is reached and that there might be diseconomies of scale above some threshold, presumably due to the complexity of managing large institutions or to the difficulties that arise when a bank's geographical coverage increases. This result is fairly robust and holds for the U.S., Europe and Canada. ${ }^{34}$ However, it relies mainly on data from the 1980s and early 1990s and, because of the small number of very large banks, relies on data from firms mostly below the size of the average bank in many countries. Also, this result might have to be revised due to recent technological changes that imply large fixed costs and thus have the potential for scale economies even for larger banks. ${ }^{35}$

On the other hand, studies of Japanese banks do find increasing returns to scale for banks of all sizes, including the largest banks. One study found that inefficiency in Japanese banks stemming from the minimum efficient scale is less than 2 per cent on average. Roughly 93 per cent of Japanese banks exhibited nonconstant returns to scale - 81 per cent of them were operating with increasing returns to scale (the rest showed decreasing returns to scale). As for different size classes, the majority of the small and medium-sized banks exhibited increasing returns to scale and anywhere from one-third to one-half of the larger banks in the survey still displayed increasing returns to scale. ${ }^{36}$ Another study found no evidence of economies of scope in Japanese banking, but did find that Japan's largest banks exhibited "appreciable scale economies." This result is attributed to the universal banking model in Japan, which provides banks with lower

\footnotetext{
${ }^{34}$ For the U.S., see Berger, Hanweck and Humphrey (1987), Berger and Mester (1997), Hughes and Mester (1998), Hunter, Timme and Yang (1990) and Noulas, Ray and Miller (1990). European references include Altunbas and Molyneux (1996), Salleo (1999) and Schure and Wagenvoort (1999); Mendes (1999) finds that smaller Portuguese banks are less efficient but face economies of scale while larger banks are more efficient but face diseconomies of scale. Lang and Welzel (1996) find moderate scale economies for all size classes but conclude that this cannot be generalized to the entire German banking sector given the small size of the banks in the sample. For Canada, see Breslaw and McIntosh (1997).

${ }^{35}$ See Berger, DeYoung, Genay and Udell (2000).

${ }^{36}$ See Fukuyama (1993).
} 
monitoring costs for their lending portfolios because of their direct participation in the ownership of many Japanese commercial businesses. ${ }^{37}$

Hughes, Mester and Moon (2001) argue that most research finds no economies of scale because it ignores differences in banks' capital structure and risk taking. They find evidence that small banks hold more capital than the cost-minimizing level, a result that they attribute to the protection of their charter values, while large banks have less than the cost-minimizing level of capital, perhaps because they exploit government subsidies to banks that are "too big to fail." The authors find that scale economies are positively associated with bank size and diversification and negatively associated with balance sheet measures of risk. They argue that scale economies are present if risk is held constant, but that these economies are masked by increased costs associated with the greater risk of larger banks. Evidence for Japan also suggests that controlling for risk reverses the more traditional results on the existence of scale economies in banking. Controlling for risk and quality factors, Altunbas, Liu, Molyneux and Seth (2000) find that the optimal bank size actually decreases, suggesting that advantages can be realized if the largest banks become smaller. This result probably reflects the fact that larger banks have seemingly lower costs but (at least in Japan) they take on proportionally more risk; once this is accounted for, scale diseconomies may appear.

The different results obtained for the U.S. and Europe on one side, and Japan on the other are perhaps not surprising given the great differences between their regulatory frameworks and financial conditions in the late 1990s. During this period, American and European banks were in good financial conditions and were exploiting legislation that expanded opportunities to diversify geographically and across product lines. At the same time, most Japanese banks were in severe financial straits and were in no condition to expand into new activities.

\footnotetext{
${ }^{37}$ See McKillop, Glass and Morikawa (1996).
} 
Probably the second most quoted reason for M\&As is the exploitation of synergies, or economies of scope: by merging with institutions specialized in different market segments, it is claimed that banks can improve their production process and cross-sell their products to a larger customer base. Measuring the existence and extent of economies of scope is especially difficult, given that, in theory, the benchmark should consist of single-product firms. The lack of such firms casts doubts on the reliability of results in this particular field.

The analysis of universal banking, conducted on European data, searches for complementarities between loans and investment-related services; however, no strong evidence has been found in favor of or against the joint provision of different services, ${ }^{38}$ but this might be due to measurement problems involving economies of scope. Scope economies have, however, been identified in smaller institutions. ${ }^{39}$ Research using American data has found find little or no revenue scope economies between bank deposits and loans. ${ }^{40}$ Some research has suggested that financial conglomerates are more revenue efficient than specialized institutions; universal banks appear to be more cost and profit efficient than nonuniversal banks. ${ }^{41}$ The true test might be about to come, when a fully unified European market will see specialized and universal banks compete against each other.

\subsection{Shareholders' Value}

The last indicator of efficiency gains is the stock market performance of merging banks. The main finding of U.S. event studies that look at share prices around the time that a deal is announced is that, on average, total shareholder value (i.e., the combined value of the bidder and the target) is not affected by the announcement

\footnotetext{
${ }^{38}$ See Allen and Rai (1996) and Lang and Welzel (1998) )

${ }^{39}$ See Lang and Welzel (1996).

${ }^{40}$ See Berger, Humphrey and Pulley (1996) and Noulas, Miller and Ray (1993).

${ }^{41}$ See Vander Vennet (1996).
} 
of the deal since, on average, the bidder suffers a loss that offsets the gains of the target. ${ }^{42}$ Therefore, M\&As imply a transfer of wealth from the shareholders of the bidder to those of the target. Interestingly enough, these results are similar to those for nonfinancial firms; ${ }^{43}$ this points in the direction of a more general problem associated with the corporate governance of M\&As. The evidence for the nineties is more favorable. Compared to the eighties, average abnormal returns have been higher for both bidders and targets. ${ }^{4}$

One problem with event studies is that the announcement of a deal mixes information concerning the proposed merger with information on its financing. Because investors consider the announcement of a stock issuance as "bad news", 45 the negative returns to the bidding bank could reflect the fact that mergers tend to be financed with stocks. Consistent with this notion, one study finds that the returns to bidders are significantly higher when mergers are financed with cash relative to mergers financed with new equity. ${ }^{46}$

Some studies have examined the stock market reaction to different types of deals. However, even these papers find no clear cut evidence on the efficiency effects of M\&As. Houston and Ryngaert (1994) find that the combined gains tend to be greater when the bidding firm is unusually profitable or there is significant overlap between institutions. The first result is consistent with a market for corporate control favoring competent over incompetent managers; the second result is consistent with a market power hypothesis, according to which higher market share leads to higher profits. $^{47}$ On the other hand, Zhang (1995) finds results consistent with a diversification hypothesis, according to which geographical

\footnotetext{
42 Rhoades (1994) and Pilloff and Santomero (1998) provide a survey of event studies. See also, Hannan and Wolken (1989) and Houston and Ryngaert (1994). However, Cornett and Tehranian (1992) find positive overall returns from banking M\&As.

${ }^{43}$ See Andrade, Mitchell and Stafford (2001).

${ }^{44}$ See Houston, James and Ryngaert (2001).

${ }^{45}$ See, e.g., Myers and Majluf (1984).

${ }^{46}$ See Houston and Ryngaert (1997).
} 
diversification leads to a lower variability of income; he finds that out-of-market transactions create value for shareholders. DeLong (2001) finds that mergers that focus banks geographically or in product space create value while those that diversify them don't.

Higher market concentration created by consolidation is likely to lead to an increase in prices for retail financial services, leading in turn to an increase in profits. However, it is also true that firms operating in more concentrated markets are generally found to be less efficient: ${ }^{48}$ this might offset the gains from an increase in market power and thus leave unchanged the market value of the bank.

In the only event study of mergers in European banking markets, Cybo-Ottone and Murgia (2000) find positive and significant gains in shareholder value from domestic bank mergers, but not from cross-border deals. They find gains both from a subsample of 54 bank-bank combinations and from a subsample of 18 mergers of banks and non-banks. However, their positive abnormal returns do not necessarily mean that mergers improve efficiency; in fact, one possible explanation for the difference between the European and American markets is that weaker antitrust enforcement in some European countries allows gains in monopoly power from in-market mergers.

\subsection{Discussion of the Main Results}

In conclusion, the empirical evidence suggests that commercial bank M\&As do not significantly improve cost and profit efficiency and, on average, do not generate significant shareholder value. There is evidence in favor of exploiting scale economies, but only up to a size well below that of the most recent large deals. Economies of scope are harder to pin down; there is no clear-cut evidence of their existence.

\footnotetext{
${ }^{47}$ See Houston and Ryngaert (1994) and Hawawini and Itzhak (1990).

${ }^{48}$ See Berger and Hannan (1998) on the relationship between market concentration and efficiency.
} 
These results seem to contradict the motivations given by practitioners for consolidation - which are largely related to issues of scale and scope economies and to improvements in management quality - and could indicate that expected efficiency gains cannot be achieved: organizational diseconomies of scale could offset any gains in scale efficiencies arising from technologies or scope economies from diversification. However, there are other possible explanations for the divergence between the econometric evidence and bankers' beliefs.

One possibility is that the deals done in the past might have suffered from stricter regulation. For example, the limitations imposed by the Glass-Steagall Act on the range of U.S. banks' financial activities could have impeded the realization of gains from cross selling. Similarly, restrictions on bank branching or to geographic expansion could have hampered the exploitation of scale economies. This view suggests that the deregulation of banking under way in all major countries (e.g., the Riegle-Neal Act or the Gramm-Leach-Bliley Act in the U.S.) might increase the potential for scale and scope economies. The evidence available for the nineties is consistent with this view.

A second possibility is that the lack of clear-cut results on the effect of M\&As could reflect difficulties in measuring the improvements in efficiency. First, during a merger wave the construction of a satisfactory control sample of nonmerging banks - which serves as a benchmark for comparison - could be very difficult: in any given year there could be only a handful of banks not involved in mergers in the previous years or in the next ones. ${ }^{49}$ Moreover, even if such a control sample could be constructed, the performance of the non-merging banks might be influenced indirectly by the consolidation of their competitors. The former could react to M\&As of their rivals by improving their efficiency, or by widening the range of products offered to their customers. Thus, measured gains from mergers relative to the control sample could understate actual gains. Second, mergers may be associated with a redistribution of resources among various

\footnotetext{
${ }^{49}$ For a discussion of this point see Calomiris and Karceski (2000).
} 
stakeholders. If M\&As are associated with an increase in competition — as it was the case in many countries in the nineties ${ }^{50}$ - consumers could reap most of the benefits from consolidation. ${ }^{51}$ This distributional change implies that the profitability ratios or stock returns would not increase even when the efficiency of the consolidating banks improves. ${ }^{52}$ Given the difficulties in measuring efficiency gains, a promising line of research could consist in analyzing case studies of merging banks in great detail, in order to select carefully the representative deals and control sample and capture industry-specific or firm-specific idiosyncrasies. ${ }^{53}$

A third alternative that has not been fully analyzed in the previous literature is that the gains from mergers can only emerge fully after some time. This means that studies restricted to a short post-merger period might fail to account for the efficiency gains of consolidation. ${ }^{54}$ Long lags in the improvement of performance may reflect difficulties in refocusing lending policies, rationalizing branches, integrating data processing systems and operations, and training the personnel of the target to market the new owner's products. ${ }^{55}$ Moreover, culture clashes may be

\footnotetext{
${ }^{50}$ For example, Angelini and Cetorelli (2003) show that the Italian banking system has become highly competitive in the 1990s. Shaffer (1993) finds that the Canadian banking system is highly competitive. Berger and Humphrey (1992b) show that the relaxation of entry restrictions has considerably increased competition among U.S. banks. A similar effect was determined by the relaxation of bank branching restrictions (see Jayaratne and Strahan, 1997).

${ }^{51}$ See for example Jayaratne and Strahan (1997).

52 On the other hand, mergers could also be associated with a redistribution of resources from the employees to the bank through lower wages (see Shleifer and Summers (1988)) or from consumers to banks, owing to an increase in market power (see Prager and Hannan (1998) for the U.S. and Focarelli and Panetta (2002) for Italy). In this case, profit ratios of merged banks could improve even when efficiency is unchanged.

${ }^{53}$ See for example Frei and Harker (1996), Calomiris and Karceski (2000) and Rhoades (1998).

54 In an analysis of the effects of M\&As in the market for bank deposits, Focarelli and Panetta (2002) find that in the short run the costs of restructuring the consolidated bank overlay the gains, which cannot fully emerge for years. In the long run, however, the efficiency gains dominate over the market power effect, leading to more favorable prices for consumers.

55 Berger, Saunders, Scalise and Udell (1998) and Calomiris and Karceski (2000) mention three years as the gestation period needed to restructure the merged bank. This squares with the results of the interviews conducted by the Federal Reserve Board staff with officials of banks involved in mergers (see Rhoades, 1998). In a study of U.S. bank mergers, Houston, James and Ryngaert (2001) find that cost savings and revenue gains take two to four years.
} 
especially harmful in banking, ${ }^{56}$ as the relationships with customers depend heavily on soft information, which is more difficult to ransfer than such objective information as balance sheet data. ${ }^{57}$ The resignation of key executives or the emergence of morale problems due to reassignments or employee turnover may cause the loss of information, especially when the new management has little time to develop customer information.

Yet another possibility is that — in the presence of agency problems between managers and shareholders — M\&As could be mainly driven by non-value maximizing motives (such as managerial hubris). Non-value maximizing motivations for M\&As have been analyzed in recent papers that examine the relation between executive compensation and $\mathrm{M} \& \mathrm{~A}$ activity. According to these studies, the motivations for M\&As could be traced back to managers' desire to increase their compensation (CEOs of larger institutions earn higher compensation). There is some evidence that CEOs with higher levels of stockbased relative to cash-based compensation are less likely to lead their institutions into making acquisitions. ${ }^{58}$ Moreover, managers without a large stake in their banks are more likely to get involved in non-value maximizing mergers. ${ }^{59}$ Managerial hubris may be an important reason for the lack of conclusive evidence on the benefits of M\&As among banks. ${ }^{60}$

\section{Insurance Companies}

The insurance industry remains heavily regulated, both in its life and property/casualty segments; this could be a restraining factor for the consolidation

\footnotetext{
${ }^{56}$ Practitioners indicate that differences in corporate cultures is one of the main obstacles to the completion of bank mergers in all the major industrial countries (see Group of Ten, 2001).

${ }^{57}$ See, for example, Rajan (1992).

${ }^{58}$ See Bliss and Rosen (2000). Similar results on the existence of agency problems in the banking industry can be found in Gorton and Rosen (1995) and Ryan (1999).

${ }^{59}$ See Palia (1993).

${ }^{60}$ See Pilloff and Santomero (1998).
} 
process, decreasing the possibility of reaping economies of scale and of diversification by discouraging in particular cross-border deals. Differences in social security systems could also contribute to the international segmentation of the life insurance industry, if countries differentiate themselves in such key variables as the age of retirement or the model of funding (defined benefits or defined contributions). Furthermore, despite a trend towards deregulation, "crossborder trade in insurance services is limited by differences in culture, consumer protection laws, taxation, and the need to establish a local presence to process claims and handle administration". 61 However, in Europe there has been greater cross-border integration in the insurance sector than in commercial banking, suggesting that European insurance managers may be better at dealing with crossborder barriers and operating efficiently in many nations.

At least within domestic markets, there is a potential for economies of scale and scope, in particular with other financial products, such as those offered by banks. These benefits may be obtained through joint ventures or through the combination of banks and insurance companies, a growing trend, especially in Europe. Finally, the proposition that there could be efficiency gains by letting the best firms take charge of the others is even more true in a sector protected, at least to an extent, from outside competition. The following sections discuss the available evidence on the insurance industry, distinguishing between the two main lines of business life and property/casualty.

\subsection{Aggregate Data}

The insurance industry seems to exhibit economies of scale, at least judging from a cursory examination of firms' balance sheet ratios. In the North American life insurance segment, management expenses as a fraction of net premiums written

\footnotetext{
${ }^{61}$ OECD (1998). See also Berger, DeYoung and Udell (2001).
} 
decrease from 16 percent for the smaller firms to 11 percent for the larger ones; in Europe the ratio decreases from 9 to 4 percent (see Table 4 ) ${ }^{62}$ As for the

Table 4

SIZE AND PERFORMANCE OF INSURANCE COMPANIES

\begin{tabular}{|c|c|c|c|c|c|c|c|}
\hline & & \multicolumn{6}{|c|}{ Life Insurance Companies by Asset Size } \\
\hline \multirow[t]{2}{*}{ Area } & \multirow[t]{2}{*}{ Variables } & \multicolumn{2}{|c|}{$<\$ 500$ mill. } & \multicolumn{2}{|c|}{$\$ 500-\$ 2000$ mill } & \multicolumn{2}{|c|}{ >\$2000 mill. } \\
\hline & & No. & Average & No. & Average & No. & Average \\
\hline \multirow{2}{*}{$\begin{array}{l}\text { North } \\
\text { America }\end{array}$} & $\frac{\text { Management Expenses }}{\text { Net Premiums Written }}$ & 72 & 16.2 & 102 & 14.0 & 134 & 10.9 \\
\hline & Return on Equity & 71 & 3.4 & 104 & 10.6 & 135 & 13.0 \\
\hline \multirow{2}{*}{ Europe } & $\begin{array}{l}\text { Management Expenses } \\
\text { Net Premiums Written }\end{array}$ & 76 & 8.6 & 86 & 5.0 & 142 & 4.4 \\
\hline & Return on Equity & 99 & 1.3 & 76 & 10.6 & 134 & 11.8 \\
\hline & & \multicolumn{6}{|c|}{ Non-Life Insurance Companies by Asset Size } \\
\hline \multirow[t]{2}{*}{ Area } & Variables & \multicolumn{2}{|c|}{ <\$100 mill. } & \multicolumn{2}{|c|}{ \$100-\$500 mill } & \multicolumn{2}{|c|}{ >\$500 mill. } \\
\hline & & No. & Average & No. & Average & No. & Average \\
\hline \multirow{2}{*}{$\begin{array}{l}\text { North } \\
\text { America }\end{array}$} & $\frac{\text { Management Expenses }}{\text { Net Premiums Written }}$ & 254 & 17.9 & 364 & 15.9 & 216 & 15.5 \\
\hline & Return on Equity & 269 & 7.2 & 373 & 9.2 & 217 & 9.5 \\
\hline \multirow{2}{*}{ Europe } & $\frac{\text { Management Expenses }}{\text { Net Premiums Written }}$ & 117 & 16.6 & 156 & 10.8 & 144 & 7.8 \\
\hline & Return on Equity & 263 & 7.2 & 183 & 9.3 & 145 & 11.2 \\
\hline
\end{tabular}

Source: Fitch-IBCA data for insurance companies; firms are ranked by assets in million U.S. dollars. All variables are averaged over the 19941997 period; the distribution is truncated at the top and bottom 10 percent.

property/casualty segment of the industry, the ratio decreases from 18 to 16 percent in North America and from 17 to 8 percent in Europe. In terms of profitability, a consistent pattern emerges: larger firms are more profitable than smaller ones. In North America, the return on equity increases from 3 to 13 percent for the life segment and from 7 to 10 percent for property/casualty firms;

62 The difference in cost levels between North America and Europe might depend on different definitions of the variables. Because of the small number of Japanese firms in the available sample, they are not included in the analysis. 
in Europe, it increases from 1 to 12 percent for life companies and from 7 to 11 percent for the property/casualty firms.

If the dispersion of cost and profit measures is used as a proxy of efficiency, then North American insurance companies appear to differ substantially in their performance: for each size class and each segment of the industry, the costs of those in the worst quartile are more than double those in the best quartile and profitability is half as high (see Table 5). The European industry reflects more or less the same pattern, suggesting that insurance companies in general could benefit from a consolidation process that would allow them to exploit scale economies and transfers of high-quality managerial skills. Of course, if the consolidation process goes too far, offsetting costs, such as those associated with the exercise of market power, may arise.

Table 5

DISPERSION OF PERFORMANCE MEASURES OF INSURANCE COMPANIES

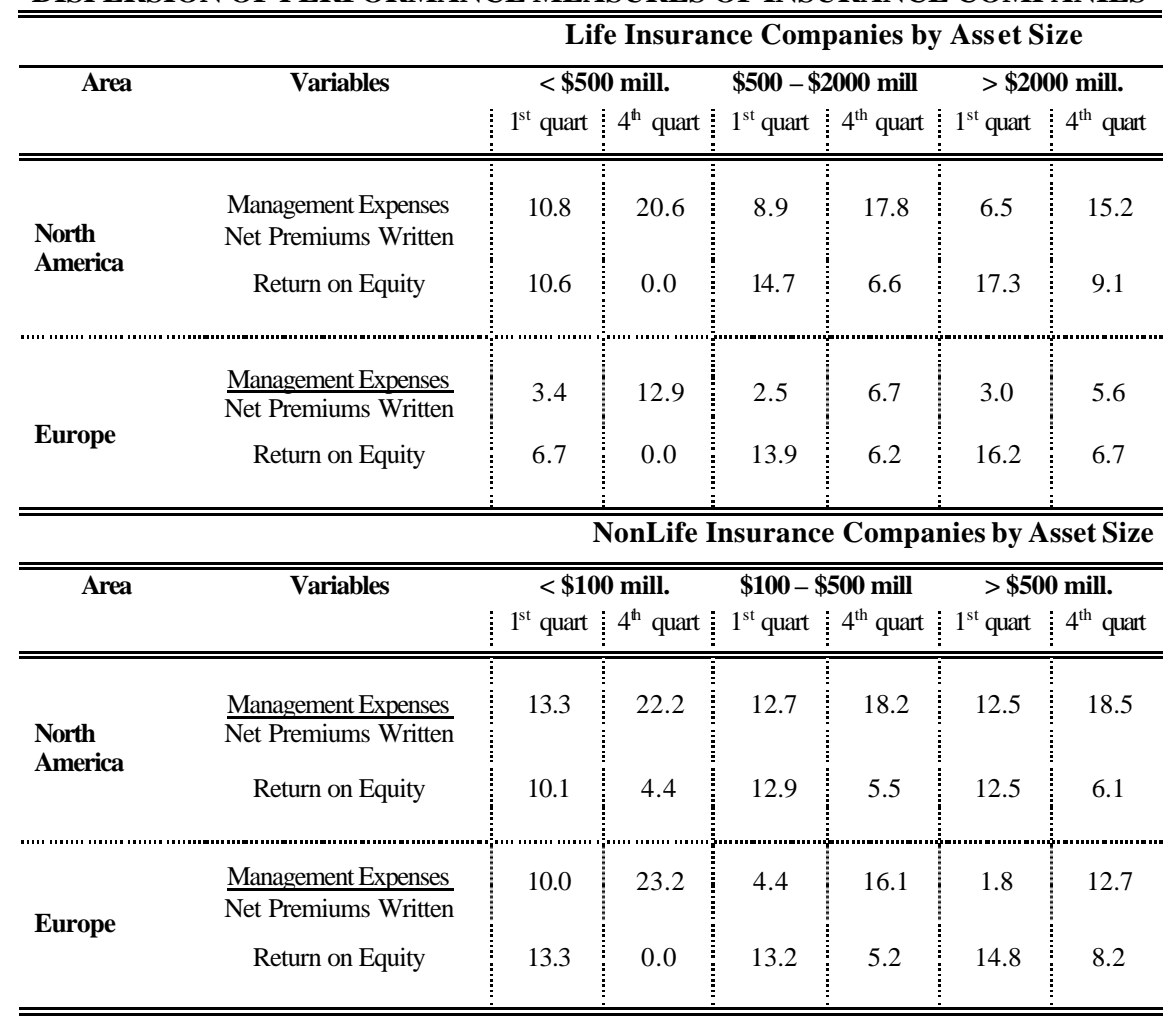

Source: Fitch-IBCA data for insurance companies; firms are ranked by assets in million U.S. dollars. All variables are averaged over the 1994-1997 period; the distribution is truncated at the top and bottom 10 percent. 


\subsection{Cost and Profit Efficiency}

The increase in productivity observed for insurance companies in all countries has been attributed to technical progress. ${ }^{63}$ However, efficiency scores vary widely by countries, the U.S. firms being on average the most efficient, i.e. with the least dispersion - the usual caveat applies on the non-comparability of efficiency scores obtained from different cost (or profit) functions (in this case, from different countries). Efficiency seems positively correlated with the reinsurance rate and negatively correlated with the share of life insurance; this might be explained by the national characteristics of the life insurance market, which deter foreign entry and thus decrease competition, allowing domestic firms to grow complacent.

U.S. property/casualty insurance companies operate at an efficiency level that varies from 80 percent of the best practice assessed for the medium-sized companies to 90 percent for the large ones, suggesting that competition keeps them from becoming too inefficient and that significant improvements from M\&As are likely only for the firms in the worst conditions. The average inefficiency level in the life segment of the insurance industry is higher, between 35 and 50 percent. $^{64}$

Cummins, Tennyson and Weiss (1999) find that M\&As improve the efficiency of target insurance firms. Because there is no evidence of increases in concentration in insurance product lines, they argue that market power is unlikely to be a motivation for mergers. Thus, the foreseeable consolidation process could benefit the industry by, for example, rationalizing the agency distribution system. As noted by Ferrier (1999), however, their use of data envelopment analysis commingles inefficiency with all other sources of error in their estimation, and their estimates of efficiency differences lack standard errors that would allow them to measure the significance of their results.

\footnotetext{
${ }^{63}$ See Donni and Fecher (1997), who use nonparametric estimation to measure the technical efficiency of the insurance industry in the OECD countries.
} 
The evidence for other countries points toward a larger gap between the best practice firms and the rest of the industry: the average efficiency level is around 50 percent for France and Belgium, around 50 percent and growing in Germany and a little higher in the British life-insurance industry. ${ }^{65}$ Given that efficiency seems to be higher in countries where the regulatory burden is lower, deregulation could help close the efficiency gap by introducing more competition.

\subsection{Scale and Scope Economies}

Scale economies in the U.S. insurance industry have been studied extensively. Property/casualty insurance companies show evidence of scale economies for small and intermediate-size firms, suggesting that consolidation among them may reduce average costs. On the other hand, larger firms exhibit diseconomies of scale. Finally, there is no evidence of scope economies at any size level. As for the life insurance industry, scale economies are found up to $\$ 15$ billion of assets, but it is unclear whether the result holds for larger firms. ${ }^{66}$

The evidence for European markets is more mixed, but in general it is in favor of the existence of scale and scope economies. ${ }^{67}$ Scale economies for life insurance have also been found for Japanese and Canadian companies. ${ }^{68}$ However, most studies use data from the early 1990s; the sweeping changes in regulation and

\footnotetext{
${ }^{64}$ See Cummins and Weiss (1993) and Gardner and Grace (1993) for property/casualty results and Yuengert (1993) for life insurance results.

65 See Delhausse, Fecher, Perelman and Pestieau (1995) for France and Belgium, Mahlberg and Url (2000) for Germany, and Rees and Kessner (1999) for the U.K.

${ }^{66}$ For property/casualty results, see Cummins and Weiss (1993) and Hanweck and Hogan (1996). For life results, see Yuengert (1993) and Cummins and $\mathrm{Zi}$ (1998). Grace and Timme (1992) find evidence of scale economies throughout their sample of life insurance firms, but they do not control for differences in the output of small and large companies.

${ }^{67}$ Focarelli (1992) finds evidence of scope economies for the life and property/casualty segments in the Italian industry; see also Prosperetti (1991). Fecher, Perelman and Pestieau (1991) find significant scale economies for both segments of the French industry. Mahlberg and Url (2000) find significant scale economies for the German market, and Kaye (1991) finds them for the British life insurance companies.

${ }^{68}$ See Fukuyama (1997) for Japan and McIntosh (1998) for Canada. Given the small number of firms in the Canadian insurance industry, McIntosh is forced to estimate a very restrictive model with one output measure that incorporates all insurance products.
} 
technology that took place in recent years might have affected deeply the cost and revenue structure of the industry. Past results, therefore, should be considered with caution.

As in other financial industries, scope economies are more elusive; the coexistence of specialized life and property/casualty insurance companies within insurance conglomerates probably means that neither diversifying nor specializing is the single winning strategy. Diversification between life insurance and property/casualty insurance produces, on average, scope diseconomies and is more suited to large insurers emphasizing personal lines of business and with vertically integrated distribution systems than it is for small insurers specializing in commercial lines of business. ${ }^{69}$ These results may be related to the desire of those buying personal lines of insurance for the convenience of buying multiple products from one supplier, but measures of convenience are not included in estimated profit efficiency equations.

\section{Investment Banks and Asset Management Companies}

M\&As involving investment banks, as well as joint ventures and strategic alliances, are increasingly common, especially between British and American investment banks and continental European commercial banks that are trying to establish a global presence. Cross-industry $M \& A s$ involving investment banks and securities dealers have been plentiful, because within the financial services sector the latter is perceived to be a growth business.

The wave of consolidation in the asset management industry has been widely driven by round-the-clock trading, the Internet, globalization, and other technology-driven advances. $^{70}$ Consolidation is also resulting from consumers' desire for the convenience of one-stop shopping. Japan and Europe are expected

\footnotetext{
${ }^{69}$ See Berger, Cummins, Weiss and Zi (2000) and Cummins and Weiss (2000).

${ }^{70}$ See Barbash (1998).
} 
to be growth areas in the future because they have lagged behind the U.S. institutional asset management industry.

\subsection{Investment Banks: Aggregate Data}

The heterogeneity of the investment banking industry, broadly defined, makes it difficult to organize a meaningful comparison across countries and size groups. The following is a tentative analysis that gives the flavor of the main differences across operators.

Table 6

\section{SIZE AND PERFORMANCE OF INVESTMENT BANKS}

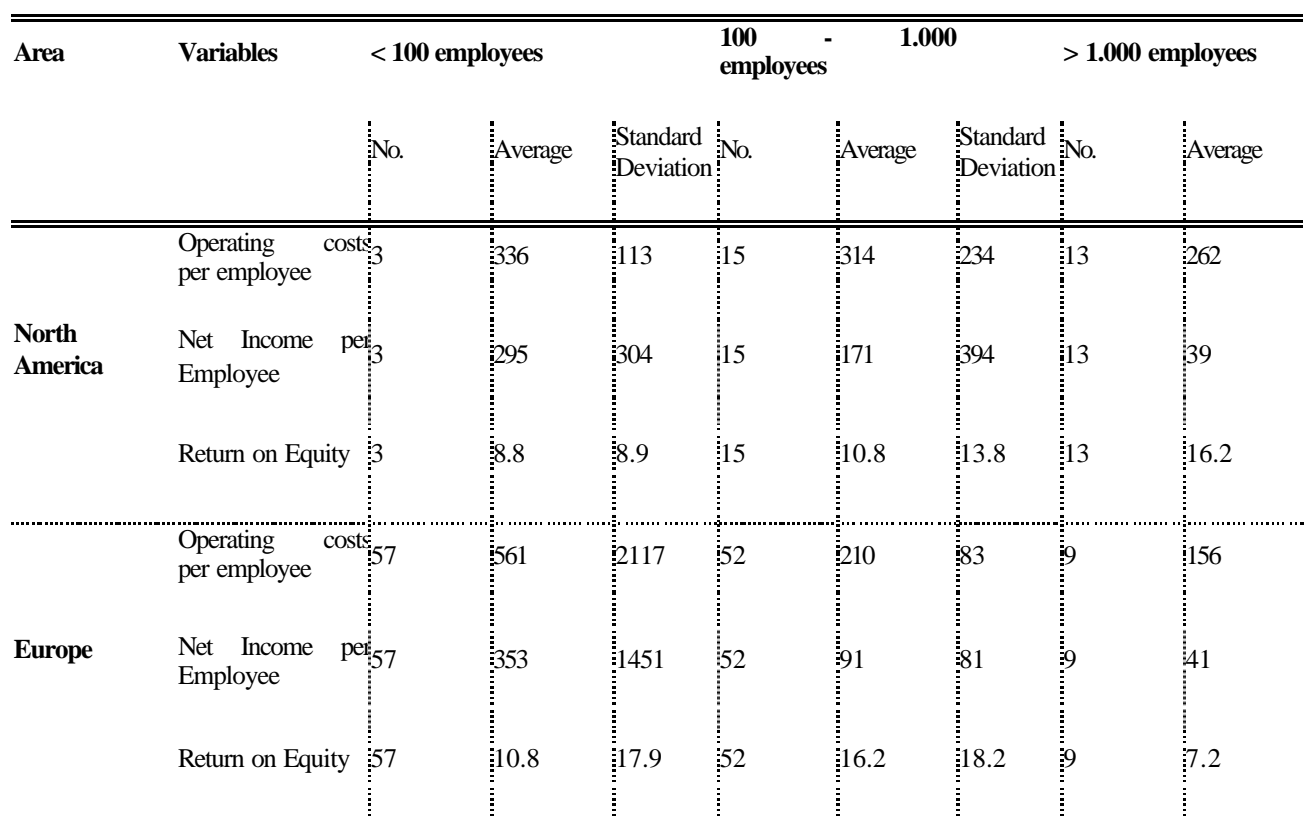

Source: Fitch-IBCA data for investment banks of G-10 countries; all variables are averaged over the 1994-1998 period; investment banks are ranked by their average number of employees over the sample period. Operating costs and net income are in thousands US dollars, reutrn on equity is expressed as a percentage value.

The investment banking industry seems more oriented towards medium-sized and larger firms (more than 100 employees) in North America, while in Europe small and medium-sized firms (fewer than 1.000 employees) dominate; this is partly due to the inclusion in the sample of organizations created mainly for tax optimization purposes. In particular, many institutions incorporate a subsidiary (with very little 
staff compared to headquarters) in countries with a favorable tax treatment of their typical sources of income.

While comparing costs and revenues across size classes makes little sense, given the vastly different horizons of firms belonging to different size brackets, for this globalized sector interesting evidence can be drawn from cross-country comparisons. North American medium-sized investment banks seem to have higher costs per employee than their European counterparts (respectively $\$ 314,000$ and $\$ 210,000)$, but their employees seem more productive $(\$ 171,000$ of net income per worker versus $\$ 91,000$ in Europe). In terms of return on equity, European banks are ahead once again (16.2 percent versus 10.8 percent for their North American competitors).

For large investment banks, the picture is slightly different: North American institutions have higher costs per employee than European ones (\$262,000 versus $\$ 156,000)$, slightly lower net income per worker $(\$ 39,000$ versus $\$ 41,000)$ but a much higher return on equity (16.2 versus 7.2 percent). This could be due to differences in capital structure (North American firms might be less capitalized than European ones) or to institutional features such as differences induced by the specialization of American banks (due to lingering effects of the Glass-Steagall Act) versus the universal bank approach of many European countries.

\subsection{Efficiency and Economies of Scale and Scope}

Unfortunately, there are no studies that examine rigorously the cost and profit performance of investment banks or asset management companies before and after mergers.

A survey of corporate strategies in the 1990s which includes case studies of recent consolidation transactions involving investment banks suggests that globalization is the main force underlying consolidation. ${ }^{71}$ Quotes from managers of merging

\footnotetext{
${ }^{71}$ See Pearson (1998).
} 
entities suggest that mergers create business synergies in areas of product offerings, product development, distribution and service. Earnings growth is often cited as an important reason for mergers, as is the need for global industry knowledge and global distribution, which demands global products, services and intelligence. ${ }^{72}$ In addition, some commentators have pointed to the increasing size of deals in recent years and suggested that banks need to have large balance sheets in order to win business and participate in various large loan syndications and equity and debt underwriting. ${ }^{73}$

Limited analytical research on scale and scope economies is available for the securities industry. ${ }^{74}$ In the U.S. economies of scale seem to exist among smaller securities firms, but they are exhausted when the firm reaches between $\$ 14$ million and \$36 million in total revenue and at about \$40 million in assets and \$4 million in equity. ${ }^{75}$ Larger firms demonstrate scale diseconomies. ${ }^{76}$ It appears, therefore, that only very small firms can expand their product mix and level of output, in the aggregate, and lower costs. Similarly, research suggests that smaller specialty firms exhibit economies of scope while large multi-product firms exhibit diseconomies of scope. The overall conclusion, however, is that economies of scope do not appear to be important in the securities industry. Neither diversified nor specialty firms above the minimum optimal scale seem to operate at a cost disadvantage.

\footnotetext{
72 See Case Study \#5, Swiss Bank Corporation, pp. 177-183, and Case Study \#11, Merrill Lynch, pp. 251257.

73 See Merrill Lynch, Banks, Brokers, and Asset Managers: Confronting the Mega-Forces in Financial Services Quarterly Review, September 2000, pp.7-8.

${ }^{74}$ As a cautionary note, the following results are based on U.S. financial data from the 1980s. This is due to the lack of research on the industry in other countries and to the fact that, where universal banking is allowed, securities are often managed by divisions of commercial banks with no readily accessible separate balance sheets.

${ }^{75}$ See Goldberg, Hanweck, Keenan and Young (1991).

${ }^{76}$ However Fukuyama and Weber (1999) and found that Japan's four largest securities firms were more cost efficient than Japan's smaller securities firms.
} 
The results outlined above might be outdated now, given the tremendous amount of change that has occurred in this sector in recent years. As a consequence, the efficient scale values found in past research, particularly for securities firms, are likely to change. As in the case of commercial banks, however, the pattern of economies of scale up to a relatively small size threshold appears to hold.

In the case of mutual fund companies, when the scale of activity expands a less than proportional increase in costs may be recorded both in the area of portfolio management (information technology and security turnover) and in shareholder servicing (record keeping and distribution). However, this happens only if asset growth is not accompanied by a large increase either in the variety of securities in the portfolio or in the number of accounts. ${ }^{77}$

For a sample of U.S. mutual funds, economies of scale at the management group level are significant, especially for smaller groups. However, if a fund's size is measured by the number of accounts, holding assets per account constant, then scale economies are far smaller. In general, there are scale economies in administering mutual funds in all size categories: the average cost curve of a typical mutual fund is downward sloping over the entire range of fund assets. For the U.S., the ratio of operating expenses to fund assets, a proxy of the managerial and administrative efficiency of a fund, declines steadily as assets grow and reaches a low of 70 basis points for the group of funds with over $\$ 5$ billion in assets. In general, large equity funds display significantly lower operating expense ratios than small funds; the reductions in fund expenses from efficiency and productivity gains are passed on by service providers as they expand the scale of their operations. ${ }^{78}$

These results are partially consistent with those found for a sample of French open-end mutual funds, for which significant scale economies are detected only

\footnotetext{
${ }^{77}$ See Baumol (1995).

${ }^{78}$ See Baumol, Goldfeld, Gordon and Koehn (1990), Latzko (1999) and Rea, Reid and Miller (1999).
} 
for small funds, while larger institutions tend to exhibit diseconomies of scale. ${ }^{79}$ According to conventional wisdom, many operating costs of asset management companies are fixed (e.g. research, trading technologies, back office) and therefore offer the possibility of exploiting scale economies. This might explain why in general companies with more assets under management given a fixed number of accounts or of funds offered to customers have higher margins. ${ }^{80}$ However larger companies suffer from a subtle diseconomy: as the size of a fund grows, it becomes less liquid and less flexible: the average trade increases in size and becomes costlier, not to mention that it might reveal valuable information to the market; this will affect negatively the portfolio performance and thus reduce the appeal of the fund to customers. ${ }^{81}$

There is also some limited econometric evidence on the presence of economies of scope in mutual funds. These results are qualitatively the same as those presented above for scale economies, with the exception that economies of scope were found to be significant for both small and large firms among French open-end mutual funds. ${ }^{82}$

The evidence in favor of the existence of some scope economies squares with the latest developments in the industry. Asset management services are often distributed jointly with other types of financial products, in order to reap the benefits from cross selling: in Europe mutual funds are sold by bank branches, while in the U.S. fund distribution is concentrated in broker-dealers and discount brokers. ${ }^{83}$ Also, life insurance companies tend to have a competitive advantage as do other more specialized firms that have established cost-effective channels of distrbution by using electronic means. In order to gain access to distribution, fund

\footnotetext{
${ }^{79}$ See Bonanni, Dermine and Röller (1998) and Dermine and Röller (1992).

${ }^{80}$ See Djelic and Sumpter (2001) for Europe and Investment Counseling, Inc.as cited in Strategic Insight (2001) for the U.S; both studies are based on surveys.

${ }^{81}$ See Beckers and Vaughan (2001).

${ }^{82}$ See Bonanni, Dermine and Röller (1998).

${ }^{83}$ See Walter (1999).
} 
management expertise and a greater international presence, a number of crossborder M\&As involving asset management firms have occurred in recent years. ${ }^{84}$ As an alternative to M\&As, many mutual fund firms have opted for strategic alliances with banks, securities broker-dealers, and insurance companies.

\section{Cross-Industry and Cross-Border Consolidation}

Research on the efficiency effects of M\&As across national boundaries and across financial industries is scarce, largely because there have been relatively few such acquisitions to date. Most studies are therefore based on simulations and indirect evidence, such as differing efficiency levels across countries.

The importance of national institutions and market structure in an international perspective is underlined by a study that compares efficiency for the financial sector (banks and insurance companies) in the OECD; measures of competition and regulation are found to be correlated with both efficiency levels and changes. ${ }^{85}$ This implies that efficient bidders active in cross-border acquisitions might find it difficult to replicate their domestic success in a different setting.

A study of European banks finds a U-shaped average costs curve and a dispersion of efficiency measures that suggests possible gains from M\&As (at least up to a certain size threshold); no distinction is made between (potential) domestic and cross-border deals. ${ }^{86}$ Changes in market structure, deriving from deregulation and consolidation, seem likely to affect mainly institutions operating in markets with low concentration and low barriers to entry; once more, national differences are shown to affect the potential effects of consolidation. In a somewhat narrow international framework, a study of banking efficiency in the Nordic countries (Finland, Norway and Sweden) decomposes individual productivity scores into a

\footnotetext{
${ }^{84}$ Examples are Mercury Asset Management (of the U.K.), purchased by Merrill Lynch, Dean Witter by Morgan Stanley and Smith Barney by Salomon Brothers.

${ }^{85}$ See Fecher and Pestieau (1993).

${ }^{86}$ See Ruthenberg and Elias (1996).
} 
within-country and an across-country part. Based on data from 1990, Swedish banks (in particular the larger ones) seem the most efficient and Finnish ones the least efficient; consolidation among Nordic banks could thus improve the productivity of their banking systems. ${ }^{87}$ However the countries considered are relatively more similar than larger groups of countries (e.g., the members of the European Union) and therefore cross-country transactions are more likely to succeed. Because of a lack of deals, there is no strong evidence yet on the results of cross-country M\&As in the financial industry.

Finally, a comparison of Italian and British investment firms (mainly brokerages and asset management firms) shows the importance of differences in the national environment. When estimated jointly, firms from both countries have similar levels of efficiency. However, once cross-country differences are allowed, British firms seem significantly more efficient than their Italian counterparts. ${ }^{88}$ This is more indirect evidence that theoretical gains from cross-country consolidation should be carefully evaluated in the light of how national differences influence cost and revenue structures.

The primary difference between within- and across-industry M\&As is the greater possibility of scope economies in mergers across industry lines - for example, through sharing physical inputs, information systems, or databases, or through consumption complementarities. There is also greater room for scope diseconomies - for example, from senior management straying far from its area of core competence.

The evidence on the possible impacts of cross-industry consolidation is mixed. Lown, et al. (2000) compute hypothetical pro forma mergers between the ten largest U.S. bank holding companies and the ten largest of three other types of financial institutions: life insurance companies, property/casualty insurance companies and securities firms. They find that bank-life insurance mergers lead to

\footnotetext{
${ }^{87}$ See Berg, Førsund, Hjalmarsson and Suominen (1993).
} 
lower profits but also to substantially lower risk and conclude that such mergers have the greatest diversification benefits (Boyd, Graham and Hewitt, 1993, find a similar result). This finding is compatible with the view that the risk of failure of bank holding companies is likely to decline and stability to increase if they can expand into non-bank financial activities. ${ }^{89}$

However, this conclusion does not hold for all combinations between banks and non-bank financial firms: Lown, et al. (2000) find that bank mergers with securities firms lead to slightly higher profits and slightly greater risk and that bank combinations with property/casualty insurers would lead to lower profits and higher risk. Moreover, while these results reflect the small number of firms that dominate the financial sector, they may not reflect the results of combinations among the large number of smaller firms in these industries. As with all simulations, they cannot anticipate changes in firm behavior that might result from the combinations. In fact, other studies have found little diversification gains from bank-securities combinations ${ }^{90}$ and increased volatility of returns and increased risk of failure. $^{91}$

The little research that exists on the efficiency effects of actual universal-type consolidation finds evidence of organizational diseconomies in universal and international integration but notes that gains from diversification can be higher than within country and within industry integration. ${ }^{92}$

There are factors that may make the efficiency consequences of international consolidation different than those for domestic M\&As. First, there may be some barriers that inhibit foreign financial institutions from operating efficiently and competing against domestic institutions. These barriers may include differences

\footnotetext{
${ }^{88}$ See Beccalli (2002).

${ }^{89}$ See also Santomero and Chung (1992).

${ }^{90}$ See Kwast (1989).

${ }^{91}$ See Boyd and Graham (1988).

${ }^{92}$ See Berger (2000).
} 
in language, culture, and regulatory or supervisory structures, and explicit or implicit rules against foreign competitors. Moreover, even if some competitors appear to have organizational advantages at home, their are unlikely to be able to apply them abroad across the board. For example small business lending is highly information-sensitive and local practices rely heavily on informal mechanisms; in order to avoid adverse selection foreign banks would have to rely on local expertise, often losing their competitive advantage. In some cases, the organizational diseconomies of operating or monitoring from a distance may be exacerbated by having to manage institutions many time zones away. ${ }^{93}$

Second, the market conditions and policies of the home nation may affect crossborder efficiency. In particular, the home market conditions (e.g., the degree of competition, the market for corporate control, or securities market development) and home market policies (e.g., banking powers, prudential regulation and supervision, and safety net guarantees) condition the environment within which institutions operate. To the extent that these differ across countries, institutions will have to adapt or they may find that the differences affect their efficiency in these international markets. Studies of cross-border efficiency usually have found that domestic banks are significantly more efficient than foreign-owned banks. ${ }^{94}$ In the most exhaustive study comparing the efficiency of domestic and foreign banks, Berger, De Young, Genay and Udell (2000) look at profit and cost efficiency differences in five countries. They find that domestic banks are generally more efficient than foreign banks, but differences are significant only in the U.S. When foreign banks are broken down by their country of origin, there are a number of instances in which foreign banks appear to have an efficiency advantage in some countries, with U.S. and German banks more often found to be more efficient in other countries (however, such comparisons are based on very

\footnotetext{
93 See Berger and DeYoung (2000). Berger, DeYoung and Udell (2001) hypothesize that operating efficiency barriers of the kinds noted above offset potential efficiency gains.

${ }^{94}$ See, for example, DeYoung and Nolle (1996), Mahajan, Rangan, and Zardkoohi (1996), Berger, DeYoung and Udell (2000) and Berger and DeYoung (2000).
} 
small samples - between four and fourteen firms - with the results for German banks sensitive to the exclusion of one company).

\section{Conclusions}

There is a general consensus that consolidation in the financial sector is beneficial up to a certain (relatively small) size in order to reap economies of scale; this holds in particular for commercial banks and insurance companies. There have been few studies on economies of scope, due to a lack of data and to measurement problems; the results are inconclusive as to whether they exist and whether they have been exploited by mergers.

As for improvements in managerial efficiency, there is no clear evidence that M\&As result in cost reduction. The most recent studies suggest that consolidation may enhance revenues, although results vary with the countries and deals analysed; moreover, the gains appear limited in magnitude. Stock markets also seem sceptical of M\&As: on average, at the announcement of a transaction, the combined value of the firms involved does not vary much, as it should if significant benefits were expected. Cross-border consolidation is relatively new and little studied; so far there is no evidence of significant gains.

However, these results are subject to an important caveat, due to the importance of innovation in shaping firms and markets. On the one hand, innovation may reduce the cost of accessing the new technology, and therefore decrease the need for larger size in order to make its adoption profitable, so that even small intermediaries could handle tasks that today are out of their reach. On the other hand, there might be cases in which new systems are profitable only if applied on a large scale, for example in the field of risk management; in the latter case, the differences between large and small institutions might increase.

Ex post results of M\&As seem to contradict the motivations given by practitioners for consolidation, which are largely related to issues of economies of scale and scope and to improvements in management quality. However to a certain extent 
this puzzle might be only apparent. The lack of clear-cut results on the effects of M\&As could reflect difficulties in measuring efficiency improvements. Further, studies restricted to short post-merger periods might fail to detect value gains that can only emerge slowly, after some years. Moreover, deals done in the past might have suffered from stricter regulation that prevented firms involved in M\&As from reaping all of the benefits of the deal. Finally, the fact that mergers often happen in waves makes it hard to separate the effect of single deals from transformations undergone by the industry as a whole.

More detailed data at the firm level are needed to measure accurately scale and scope economies and to gauge the effects of changes in management. International comparisons are difficult due to differences in regulation and technology, and the consequent differences in markets for financial products. However, changes in regulation and technology within countries have been going on for long enough that it should be possible to study their impact on the industry.

One issue that deserves more attention in future research is how M\&As affect the risk of the institutions involved and of the industry. Most studies have dealt with the potential gains from M\&As in terms of operating costs and profits, but, given the nature of financial institutions, the trade-off with risk is crucial for a general assessment of the effects of consolidation. Finally, an international coverage that would apply broadly similar methodologies to a wide range of countries for a sufficient time span would help distinguish what are the deep parameters that govern the evolution of the financial industry from characteristics that stem from national practices or regulations. 


\section{References}

Akhavein, Jalal D., Allen N. Berger and David B. Humphrey (1997), "The Effects of Megamergers on Efficiency and Prices: Evidence from a Bank Profit Function," Review of Industrial Organization 12(1), 95-139.

Allen, Linda, and Anoop Rai (1996), "Operational Efficiency in Banking: An International Comparison," Journal of Banking and Finance 18(6), 655-672.

Altunbas, Yener, Ming-Hau Liu, Philip Molyneux and Rama Seth (2000), "Efficiency and Risk in Japanese Banking," Journal of Banking and Finance 24(10), 1605-1628.

Altunbas, Yener, and Philip Molyneux (1996), "Economies of Scale and Scope in European Banking," Applied Financial Economics 6(4), 367-375.

Altunbas, Yener, Philip Molyneux and John Thornton (1997) "Big-Bank Mergers in Europe: An Analysis of the Cost Implications," Economica 64(264), 317329.

Andrade Gregor, Mark Mitchell and Erik Stafford (2001), "New Evidence and Perspectives on Mergers," Journal of Economic Perspectives 15(2), 103-120.

Angelini, Paolo, and Nicola Cetorelli (2003), "The Effects of Regulatory Reforms on Competition in the Banking Industry," forthcoming, Journal of Money, Credit and Banking .

Barbash, B. P. (1998), Mutual Fund Consolidation: Challenges for the Future, speech by SEC staff to the Mutual Fund and Investment Management Conference on March 23.

Baumol, William J. (1995), "Economies of Scale in Financial Activities," The New Palgrave Dictionary of Money and Finance, Macmillan: London, 726728.

Baumol, William J., Michael F. Koehn, Stephen M. Goldfeld and Lilli A. Gordon (1990), "The Economics of Mutual Funds Markets: Competition Versus Regulation," Rochester Studies in Economics and Policy Issues, Kluwer: Boston.

Beccalli, Elena (2002), "Efficiency and Profitability Test of Investment Firms: A Comparison Between the UK and Italian Industries," presented at EFA Berlin.

Beckers, S., and G. Vaughan (2001), "S mall Is Beautiful - An Attempt to Quantify the Competitive Disadvantage of Large Asset Managers," The Journal of Portfolio Management, 9-17.

Berg, Sigbjørn A., Finn R. Førsund, Lennart Hjalmarsson and Matti Suominen (1993), "Banking Efficiency in the Nordic Countries," Journal of Banking and Finance 17, 371-388.

Berger, Allen N. (1998), "The Efficiency Effects of Bank Mergers and Acquisitions: A Preliminary Look at the 1990s Data," in Y. Amihud and G. 
Miller eds., Bank Mergers and Acquisitions, Kluwer Academic: Boston, 79111.

Berger, Allen N. (2000) "The Integration of the Financial Services Industry: Where are the Efficiencies?" North American Actuarial Journal4.

Berger, Allen N., J. David Cummins, and Mary A. Weiss (1997), "The CoExistence of Multiple Distribution Systems for Financial Services: The Case of Property-Liability Insurance," The Journal of Business 70(4), 515-546.

Berger, Allen N., J. David Cummins, Mary A. Weiss and Hongmin Zi (2000), "Conglomeration versus Strategic Focus: Evidence from the Insurance Industry," Board of Governors of the Federal Reserve System.

Berger, Allen N., R. Demsetz and P. Strahan (1999), "The Consolidation of the Financial Services Industry: Causes, Consequences, and Implications for the Future," Journal of Banking and Finance 23(2-4), 135-194.

Berger, Allen N., and Robert DeYoung (1996), "Problem Loans and Cost Efficiency in Commercial Banks," Board of Governors of the Federal Reserve System.

Berger, Allen N., and Robert DeYoung (2000), "The Financial Performance of Cross-Regional Commercial Banks in the U.S.: Some Clues Regarding the Eventual Structure of a Consolidating Industry," Board of Governors of the Federal Reserve System.

Berger, Allen N., Robert DeYoung, Hesna Genay and Gregory F. Udell (2000), "The Globalization of Financial Institutions: Evidence from Cross-Border Banking Performance," Brookings-Wharton Papers on Financial Services 3, 23-158.

Berger, Allen N., Robert DeYoung and Gregory F. Udell (2001), "Efficiency Barriers to the Consolidation of the European Financial Services Industry," European Financial Management7(1) 117-130.

Berger, Allen N., Diana Hancock and David B. Humphrey (1993), "Bank Efficiency Derived from the Profit Function," Journal of Banking and Finance 17(2-3), 317-347.

Berger, Allen N., and Timothy H. Hannan (1998), "The Efficiency Cost of Market Power in the Banking Industry: A Test of 'Quiet Life' and Related Hypotheses," Review of Economics and Statistics 80(3), 154-165.

Berger, Allen N., Gerald A. Hanweck and David B. Humphrey (1987), "Competitive Viability in Banking: Scale, Scope and Product Mix Economies," Journal of Monetary Economics 20(3), 501-520.

Berger, Allen N., and D. Humphrey (1992a), "The Megamergers in Banking and the Use of Cost Efficiency as an Antitrust Device," Antitrust Bulletin, Fall.

Berger, Allen N., and David B. Humphrey (1992b), "Measurement and Efficiency Issues in Commercial Banking," in Zvi Griliches, ed., Output Measurement in the Service Sectors, NBER Studies in Income and Wealth 56, University of Chicago Press: Chicago and London, 245-279. 
Berger, Allen N., and David B. Humphrey (1997), "Efficiency of Financial Institutions: International Survey and Directions for Future Research," Board of Governors of the Federal Reserve System, Finance and Economics Discussion Paper Series, no. 11.

Berger, Allen N., David B. Humphrey and Lawrence B. Pulley (1996), "Do Consumers Pay for One-Stop Banking? Evidence from an Alternative Revenue Function," Journal of Banking and Finance 20(9), 160-201.

Berger, Allen N., and Loretta J. Mester (1997), "Inside the Black Box: What Explains the Differences in the Efficiencies of Financial Institutions?" Journal of Banking and Finance 21, 895-947.

Berger, Allen N., Nathan Miller, Mitchell Petersen, Raghuram Rajan and Jeremy Stein (2002), "Does Function Follow Organizational Form? Evidence from the Lending Practices of Large and Small Banks", NBER Working Paper 8752, February.

Berger, A. N., A. Saunders, J. Scalise and G. Udell (1998), "The Effects of Bank Mergers and Acquisitions on Small Business Lending," Journal of Financial Economics 50, 187-229.

Bliss, Richard T., and Richard J. Rosen (2001), "CEO Compensation and Bank Mergers," Journal of Financial Economics 61(1), 107-38.

Bonanni, C., J. Dermine and L. H. Roller (1998), "Some Evidence on Customer 'Lock-In' in the French Mutual Funds Industry," Applied Economics Letters 5(5), 275-279.

Boyd, John, Stanley Graham, and Shawn Hewitt (1993), "Bank Holding Company Mergers with Nonbank Financial Firms: Effects on the Risk of Failure," Journal of Banking and Finance 17, 43-63.

Breslaw, Jon A. and James McIntosh (1997), "Scale Efficiency in Canadian Trust Companies," Journal of Productivity Analysis 8, 281-92.

Calomiris, Charles W., and Jason Karceski (2000), "Is The Bank Merger Wave of the 1990s Efficient? Lesson from Nine Case Studies," in S. Kaplan, Mergers and Productivity, University of Chicago Press/NBER: Chicago.

Clark, Jeffrey A., and Thomas F. Siems (1997), "Rethinking Bank Efficiency and Regulation: How Off-Balance Sheet Activities Make a Difference," Financial Industry Studies, 1-12.

Cornett, Marcia Millon, and Hassan Tehranian (1992), "Changes in Corporate Performance Associated With Bank Acquisitions," Journal of Financial Economics 31(2), 211-234.

Cummins, J. David, Sharon Tennyson and Mary A. Weiss (1999), "Consolidation and Efficiency in the US Life Insurance Industry," Journal of Banking and Finance 23, 325-357. 
Cummins, J. David, and Mary A. Weiss (1993), "Measuring Cost Efficiency in the Property-Liability Insurance Industry," Journal of Banking and Finance 17(2-3), 463-482.

Cummins, J. David, and Mary A. Weiss (2000), "The Global Market for Reinsurance: Consolidation, Capacity, and Efficiency," Brookings-Wharton Papers on Financial Services 3, 159-222.

Cummins, J. David, and Hongmin Zi (1998), "Comparison of Frontier Efficiency Methods: An Application to the U.S. Life Insurance Industry," Journal of Productivity Analysis 10(2), 131-152.

Cybo-Ottone, Alberto, and Maurizio Murgia (2000), "Mergers and Shareholder Wealth in European Banking," Journal of Banking and Finance 24(6), 831859.

DeLong, Gayle L. (2001) "Stockholder Gains From Focusing Versus Diversifying Bank Mergers," Journal of Financial Economics 59(2), 221-252.

De Young, Robert (1997), "Bank Mergers, X-Efficiency and the Market for Corporate Control," Managerial Finance 23, 32-47.

De Young, Robert, and Daniel E. Nolle (1996), "Foreign-Owned Banks in the U.S.: Earning Market Share or Buying It?" Journal of Money, Credit, and Banking 28(4), 622-636.

Delhausse, B., Fabienne Fecher, Sergio Perelman and Pierre Pestieau (1995), "Measuring Productive Performance in the Non-Life Insurance Industry: The Case of French and Belgian Markets," Tijdschrift Voor Economic en Management 40, 47-69.

Demsetz, Rebecca S., and Philip E. Strahan (1997), "Diversification, Size, and Risk at Bank Holding Companies," Journal of Money, Credit, and Banking 29(3), 300-313.

Dermine, Jean, and Lars-Hendrik Roller (1992) "Economies of Scale and Scope in French Mutual Funds," Journal of Financial Intermediation 2(1), 83-93.

Dietsch, Michel, and Ana Lozano-Vives (2000), "How the Environment Determines Banking Efficiency: A Comparison Between French and Spanish Industries," Journal of Banking and Finance 24(6) 985-1004.

Diewert, W.E. (1974), "Applications of Duality Theory," in M.D. Intriligator and D.A. Kendrick, eds., Frontiers of Quantitative Economics, vol. II, 106-208.

Djelic B. and J. Sumpter (2001), "Will the Goose Keep Laying Golden Eggs? The Second Survey on the Profitability of European Asset Management," McKinsey \& Co: Paris.

Donni, Olivier, and Fabienne Fecher (1997), "Efficiency and Productivity of the Insurance Industry in the OECD Countries," Geneva Papers on Risk and Insurance 22(85), 523-535.

Esho, Neil (2001), "The Determinants of Cost Efficiency in Cooperative Financial Institutions: Australian Evidence," Journal of Banking and Finance 25(5) 941964. 
Fecher, Fabienne, Sergio Perelman and Pierre Pestieau (1991), "Scale Economies and Performance in the French Insurance Industry," Geneva Papers on Risk and Insurance 16(60), 315-326.

Fecher, Fabienne, and Pierre Pestieau (1993), "Efficiency and Competition in O.E.C.D. Financial Services," in Harold O. Fried, Knox C.A. Lovell and Shelton S. Schmidt, eds., The Measurement of Productive Efficiency: Techniques and Applications.

Ferrier, G.D. (1999), "Comment on Hughes, Lang, Mester and Moon and Cummins, Tennyson and Weiss," Journal of Banking and Finance 23(2-4) 358-366.

Focarelli, Dario (1992), "Economie di Scala e della Diversificazione Produttiva nel Settore Assicurativo," Rivista di Politica Economica 82(4), 23-44.

Focarelli, D., and F. Panetta (2002), "Are Mergers Beneficial to Consumers? Evidence from the Market for Bank Deposits," Paper presented at the XXXIII Chicago Fed Conference on Bank Structure, Chicago, May.

Focarelli, D., F. Panetta and C. Salleo (2002). "Why Do Banks Merge?" forthcoming, Journal of Money Credit, and Banking .

Frei, F., and P. Harker (1996), "Measuring the Efficiency of Service Delivery Processes: With Application to Retail Banking," Working Paper 96-31, Wharton Financial Institutions Center, University of Pennsylvania.

Fukuyama (1993)

Fukuyama, Hirofumi (1997), "Investigating Productive Efficiency and Productivity Changes of Japanese Life Insurance Companies," Pacific Basin Finance Journal 5(4), 481-509.

Fukuyama, Hirofumi, and William L. Weber (1999), "The Efficiency and Productivity of Japanese Securities Firms, 1988-93", Japan and the World Economy 11, 115-133.

Gardner, Lisa A., and Martin F. Grace (1993), "X-Efficiency in the U.S. Life Insurance Industry," Journal of Banking and Finance 17(2-3), 497-510.

Goldberg, L. G., G.A. Hanweck, M. Keenan. and A. Young (1991), "Economies of Scale and Scope in the Securities Industry," in Journal of Banking and Finance, 15.

Gorton, Gary, and Richard Rosen (1995), "Corporate Control, Portfolio Choice, and the Decline of Banking," Journal of Finance 50, 1377-1420.

Grace, Martin F., and Stephen G. Timme (1992), "An Examination of Cost Economies in the U.S. Life Insurance Industry," Journal of Risk and Insurance 59(1), 72-103.

Group of Ten (2001), Report on Consolidation in the Financial Sector, Bank for International Settlements: Basel, Switzerland. 
Haynes, Michelle, and Steve Thompson (1999), "The Productivity Effects of Bank Mergers: Evidence from the UK Building Societies," Journal of Banking and Finance 23(5), 825-846.

Hannan, Timothy H., and John D. Wolken (1989), "Returns to Bidders and Targets in the Acquisition Process: Evidence from the Banking Industry," Journal of Financial Services Research 3(1), 5-16.

Hanweck, Gerald A., and Arthur M.B. Hogan (1996), "The Structure of the Property/Casualty Insurance Industry," Journal of Economics and Business 48(2), 141-155.

Houston, Joel F., and Michael D. Ryngaert (1994), "The Overall Gains From Large Bank Mergers," Journal of Banking and Finance 18(6), 1155-1176.

Houston, Joel F., and Michael D. Ryngaert (1997), "Equity Issuance and Adverse Selection: A Direct Test Using Conditional Stock Offers," Journal of Finance 52(1), 197-219.

Houston, J., C. James and M. Ryngaert (2001), "Where Do Merger Gains Come From? Bank Mergers from the Perspective of Insiders and Outsiders," Journal of Financial Economics, 60(2-3), 285-331.

Hughes, Joseph P., and Loretta J. Mester (1998), "Bank Capitalization and Cost: Evidence of Scale Economies in Risk Management and Signaling," Review of Economics and Statistics 80(2), 314-325.

Hughes, Joseph P., Loretta J. Mester and Choon-Geol Moon (2001), "Are Scale Economies in Banking Elusive or Illusive? Evidence Obtained by Incorporating Capital Structure and Risk-Taking into Models of Bank Production," Journal of Banking and Finance 25(12), 2169-2208.

Hunter, William C., Stephen G. Timme and Won-Keun Yang (1990), "An Examination of Cost Sub-Additivity and Multiproduct Production in Large U.S. Banks," Journal of Money, Credit, and Banking 22(4), 504-525.

Jayaratne, Jith, and Philip E. Strahan (1997), "Entry Restrictions, Industry Evolution, and Dynamic Efficiency: Evidence from Commercial Banking," Staff Report 22, Federal Reserve Bank of New York.

Kaye, Geraldine (1991), "Economies of Scale in U.K: Life Insurance Companies: An Empirical Approach," Geneva Papers on Risk and Insurance 16(60), 302314.

Kennickel Arthur B., Martha Starr-McCluer and Annika Sunden (1997), "Family Finances in the U.S.: Recent Evidence from the Survey of Consumer Finances," Federal Reserve Bulletin 83(1), 1-24.

Kwast, Myron L. (1989), "The Impact of Underwriting and Dealing on Bank Returns and Risks," Journal of Banking and Finance 13(1), 101-125.

Kwast, Myron L., Martha Starr-McCluer and John D. Wolken (1997), "Market Definition and the Analysis of Antitrust in Banking," Antitrust Bulletin 42, 973. 
Lang, Gunter, and Peter Welzel (1996) "Efficiency and Technical Progress in Banking. Empirical Results for a Panel of German Cooperative Banks," Journal of Banking and Finance 20, 1002-1023.

Lang, Gunter, and Peter Welzel (1998), "Technology and Cost Efficiency in Universal Banking: A 'Thick-Frontier' Analysis of the German Banking Industry," Journal of Productivity Analysis 10(1), 63-84.

Latzko, David A. (1999), "Economies of Scale in Mutual Fund Administration," Journal of Financial Research 22(3), 331-339.

Linder, Jane C., and Dwight B. Crane (1993), "Bank Mergers: Integration and Profitability," Journal of Financial Services Research 7(1), 35-55.

Lown, Cara S., Carol L. Osler, Philip E. Strahan, and Amir Sufi (2000), "The Changing Landscape of the Financial Services Industry: What Lies Ahead?" FRBNY Economic Policy Review, October, 39-55.

Mahajan, Arvind, Nanda Rangan and Ashgar Zardkoohi (1996), "Cost Structures in Multinational and Domestic Banking," Journal of Banking and Finance 20(2), 238-306.

Mahlberg and Url (2000)

McIntosh, James (1998), "Scale Efficiency in a Dynamic Model of Canadian Insurance Companies," The Journal of Risk and Insurance 65(2) 303-317.

McKillop, Glass and Morikawa (1996)

Mendes, Victor (1999), "Productive Efficiency, Technological Change and Productivity in Portuguese Banking," Applied Financial Economics 9(5), 513.

Merrill Lynch (2000), "Banks, Brokers, and Asset Managers: Confronting the Mega-Forces," Financial Services Quarterly Review, September.

Mester, Loretta J. (1996), "A Study of Bank Efficiency Taking into Account RiskPreferences," Journal of Banking and Finance 20(6) 1025-1045.

Myers, Stewart C., and Nicholas S. Majluf (1984), "Corporate Financing and Investment Decisions When Firms Have Information That Investors Do Not Have," Journal of Financial Economics 13, 187-221.

Noulas, Athanasios G., Subash C. Ray and Stephen M. Miller (1990), "Returns to Scale and Input Substitution for Large U.S. Banks," Journal of Money, Credit, and Banking 22(1), 94-108.

OECD (1998), "Competition and Related Regulation Issues in the Insurance Sector," DAFFE/CLP (98) (20).

OECD (1999), "Background Note on Mergers and Acquisitions in the Financial Services Sector," DAFFE/CMF (99) (20).

Palia, D., (1993), "Recent Evidence on Bank Mergers," Financial Markets, Institutions, and Instruments, December, 36-59.

Pearson, Michael (1998), Mergers and Acquisitions in Finacial Services: A Global Analysis of M\&As and Corporate Strategies in the 1990s, Lafferty Publications Ltd.: Dublin. 
Peristiani, Stavros (1997), "Do Mergers Improve the X-Efficiency and Scale Efficiency of U.S. Banks? Evidence from the 80s," Journal of Money, Credit, and Banking 29(3), 326-337.

Pilloff, Steven J. (1996), "Performance Changes and Shareholder Wealth Creation Associated with Mergers of Publicly Traded Banking Institutions," Journal of Money, Credit, and Banking 28(3), 59-78.

Pilloff, Steven J., and Anthony M. Santomero (1998), "The Value Effect of Bank Mergers and Acquisitions," in Y. Amihud and G. Miller, eds., Bank Mergers and Acquisitions, Kluwer Academic: Boston.

Prager, Robin, and Timothy H. Hannan (1998), "Do Substantial Horizontal Mergers Generate Significant Price Effects? Evidence From the Banking Industry," The Journal of Industrial Economics 46, 433-452.

Prosperetti, Luigi (1991), "Economies of Scale in Italian Non-Life Insurance," Geneva Papers on Risk and Insurance 16(60), 282-292.

Rea, J.D., B.K. Reid and K.W. Miller (1999), "Operating Expense Ratios, Assets, and Economies of Scale in Equity Mutual Funds," in Investment Company Institute 5(5), December.

Rees, Ray, and Ekkehard Kessner (1999), "Regulation and Efficiency in European Insurance Markets," Economic Policy: A European Forum 0(29), 363-392.

Rhoades, Stephen A. (1993), "Efficiency Effects of Horizontal (In-Market) Bank Mergers," Journal of Banking and Finance 17(2-3), 411-422.

Rhoades, Stephen A. (1994), "A Summary of Merger Performance Studies in Banking, 1980-93, and an Assessment of the 'Operating Performance' and 'Event Study' Methodologies,' Federal Reserve Board Staff Study No. 167.

Rhoades, Stephen A. (1998), "The Efficiency Effects of Bank Mergers: An Overview of Case Studies of Nine Mergers," Journal of Banking and Finance 22, 273-91.

Ruthenberg. David, and Ricky Elias (1996), "Cost Economies and Interest Rate Margins in a Unified European Banking Market," Journal of Economics and Business 48, 231-249.

Ryan, Sean J. (1999) "Finding Value in Bank Mergers," in Proceedings of the $35^{\text {th }}$ Annual Conference on Bank Structure and Competition, Federal Reserve Bank of Chicago, 548-552

Salleo, Carmelo (1999), "Efficiency and Economies of Scale: The Case of Italian Banks," in Essays in Banking and Corporate Finance, PhD Dissertation, Harvard University.

Santomero, Anthony, and Eek-June Chung (1992) "Evidence in Support of Broader Bank Powers," Financial Markets, Institutions and Instruments 1(1), $1-69$.

Sapienza Paola (2002), "The Effects of Banking Mergers on Loan Contracts," Journal of Finance 57, 329-368. 
Sathye, Milind (2001), "X-efficiency in Australian Banking: An Empirical Investigation," Journal of Banking and Finance 25(3) 613-630.

Shaffer, Sherrill (1993), "A Test of Competition in Canadian Banking," Journal of Money, Credit, and Banking 25, 49-61.

Shleifer, A., and L. Summers (1988), "Breach of Trust in Hostile Takeovers," in Alan Auerbach, ed., Corporate Takeovers: Causes and Consequences, University of Chicago Press: Chicago.

Schure, Paul, and Rien Wagenvoort (1999) "Economies of Scale and Efficiency in Euopean Banking: New Evidence," European Investment Bank Economic and Financial Reports 99/01.

Srinivasan, Aruna (1992), “Are There Cost Savings from Bank Mergers?" Federal Reserve Bank of Atlanta Economic Review 77(2), 17-28.

Strategic Insight (2001), Money Management Financial Comparisons 2000, Strategic Insight Mutual Fund Research and Consulting LLC: New York.

Vander Vennet, R. (1996), "The Effect of M\&As on the Efficiency and Profitability of EC Credit Institutions," Journal of Banking and Finance 20, 1531-1558.

Walter, I. (1999), “The Global Asset Management Industry: Competitive Structure and Performance," Financial Markets, Institutions and Instruments 8(1).

Yuengert, Andrew W. (1993), "The Measurement of Efficiency in Life Insurance: Estimates of a Mixed NormalGamma Error Model," Journal of Banking and Finance 17(2-3), 483-496.

Zhang, Hao (1995), "Wealth Effects of U.S. Bank Takeovers," Applied Financial Economics 5(5), 329-336. 